\title{
Experimental Models of Schistosoma mansoni Infection
}

\author{
Allen W Cheever, Jane A Lenzi*, Henrique L Lenzi*, Zilton A Andrade**/+ \\ Biomedical Research Institute, MD 20852-1709, USA *Departamento de Patologia, Instituto Oswaldo Cruz-Fiocruz, \\ Rio de Janeiro, RJ, Brasil **Laboratório de Patologia Experimental, Centro de Pesquisas Gonçalo Moniz-Fiocruz, \\ Rua Valdemar Falcão 121, 40295-001 Salvador, BA, Brasil
}

Experimental models of Schistosoma mansoni infections in mammals have contributed greatly to our understanding of the pathology and pathogenesis of infection. We consider here hepatic and extrahepatic disease in models of acute and chronic infection. Experimental schistosome infections have also contributed more broadly to our understanding of granulomatous inflammation and our understanding of Th1 versus Th2 related inflammation and particularly to Th2-mediated fibrosis of the liver.

Key words: Schistosoma mansoni - experimental models - schistosomiasis

Experimental schistosome infections of laboratory animals have frequently been used to model the anatomopathologic and pathophysiologic features of the infection in humans as well as for the study of immunity and treatment. We concentrate here on the anatomic and parasitologic features of various models and on the use of models to address mechanisms of pathogenesis. Reviews dealing with immunopathology (Lukacs \& Boros 1993, Wynn \& Cheever 1995, Cheever \& Yap 1997, Fallon 2000) and with immunization and resistance to reinfection (James 1995, Richter et al. 1995, Coulson 1997, Waine \& McManus 1997, Bergquist \& Colley 1998) have been recently published.

Schistosoma mansoni matures over a 5 week (wk) period in permissive hosts such as the mouse and egg laying begins at that time. Most pathology in schistosome infected animals is attributed to the host's reaction to the eggs which is maximal by the 8th wk of infection. Granulomas are composed principally of macrophages, eosinophils and lymphocytes with the proportion of cells varying in different organs (Weinstock \& Boros 1983a). Natural killer cells may comprise over $20 \%$ of cells in the granuloma (Remick et al. 1988), but these produced little IFN- $\gamma$ (Rakasz et al. 1998). Mast cells are infrequent in 8wk granulomas in most mouse strains and become more frequent in chronic infections (Weinstock \& Boros 1983b) and these may be important because they secrete fibrogenic mediators and interact with hepatic stellate (Ito) cells (Brito \& Borojevic 1997). Chesney et al. (1998) described the infiltration of circulating "fibrocytes" into granulomas and speculate that these cells may be important for attracting CD4+ lymphocytes as well as for collagen formation.

After the 8th wk of infection there is downmodulation of the immune reaction and granulomas around recently deposited eggs become progressively smaller (Andrade \& Warren 1964, Chensue \& Boros 1979). Although the

${ }^{+}$Corresponding author. Fax: +55-71-356-4320, Ext. 206.

E-mail: zilton@cpqgm.fiocruz.br

Received 15 August 2002

Accepted 18 September 2002 response to new eggs is downregulated, cumulative damage occurs as older lesions involute to leave fibrous scars. Thus the rate of damage decreases but accumulated damage may increase, the balance being determined by the variable ability of the host to kill worms, to inhibit worm fecundity and to destroy eggs and repair tissue damage. The rhesus monkey does all these things very well and shows no residual damage after the infection has cleared or been treated (Cheever \& Powers 1969, 1971). The baboon and cercopithecus monkey destroy eggs rapidly and repair tissue damage (or perhaps never synthesize much collagen) but kill worms slowly and inhibit oviposition slightly (Cheever \& Duvall 1974) and there is little cumulative damage. In the chimpanzee worm fecundity is maintained and hepatic collagen and obstructive portal lesions accumulate (Sadun et al. 1970). Major findings in the varied species used to examine $S$. mansoni infections are summarized in Tables I-IV.

Schistosome infected animals are exposed to antigens from the developing worms during the $5 \mathrm{wk}$ before egg deposition begins. The interpretation of immune reactions to the eggs is complicated by this previous exposure to antigens, including antigens cross-reactive with egg antigens (Lukacs \& Boros 1991). Unisexually infected mice and mice sensitized to many worm antigens are also sensitized to egg antigens and have an augmented and accelerated response to injected eggs (Cheever et al. 1997, Jacobs et al. 1997a, 1998c), in unexplained contrast to the report of Warren and Domingo (1970).

The intravenous injection of eggs initiates synchronous granulomas in the lung of a host which may be naive to schistosome antigens or treated in a defined fashion. The subsequent development of the granulomas is not entirely synchronous, but these lesions are more easily studied than the completely non-synchronized granulomas resulting from infection. The lung model is not, however, a substitute for the study of infected animals. The antigenic quality of the eggs injected may affect both the size of the granuloma and the effects of treatment on the granuloma (Eltoum et al. 1995).

Beads coated with schistosome egg antigens, antigen fractions or recombinant antigens may also be injected intravenously or used in vitro (Parra et al. 1991, Oliveira et al. 2000). Injection of beads or eggs into the portal vein 
has been employed less frequently. Some investigators have found naive mice nonresponsive to eggs injected into the portal vein (Leptak \& McKerrow 1997) and that portal (Cuison et al. 1995) or enteric (Weinstock et al. 1985) injection of eggs induced tolerance to eggs subsequently injected. Others have not noted this effect and have used portal injection as they would the lung model (Edungbola \& Schiller 1979, Raso et al. 1983, Eltoum et al. 1995, Jacobs et al. 1997a, 1999).

Granulomas in the mouse lung induce much less fibrosis than granulomas in the liver and although it is possible to study fibrosis in the lung model (Boros et al. 1983, Metzger \& Peterson 1988), the high background levels of matrix and the low levels of fibrosis induced (Cheever et al. unpublished) complicate this use of the lung model. Examination of collagen mRNA levels in the lung (Warmington et al. 1999) will doubtless be increasingly used as will determination of mRNA for proteases.

\section{GENERAL CONSIDERATIONS IN THE INTERPRETATION} OF MODELS OF SCHISTOSOME INFECTIONS

A. The intensity of experimental schistosome infections is generally extremely high. A single $S$. mansoni worm pair in a mouse may be equivalent to more than 1,000 pairs in an infected person (Cheever 1969, Gryseels $\&$ de Vlas 1996).

B. Most schistosome infections in humans are acquired gradually over years while most experimental infections are given as a single exposure. When a mouse is given multiple inocula, the cumulative intensity of infection becomes progressively less realistic.

C. Most humans exposed to schistosomiasis are born to mothers who are or have been infected. There are ample reasons to think that in utero exposure to schistosome antigens or to idiotypic or anti-idiotypic antibodies may modify the response to subsequent infection in humans (Eloi-Santos et al. 1989, Novato-Silva et al. 1992) and in mice (Montesano et. al. 1997, 1999a, b).

D. The chronicity of schistosome infections in humans is obviously not reproducible in most animal models. Although one may predict that in some respects a week or two in the life of a mouse may be equivalent to a year in humans, the calculation of equivalent times is uncertain.

E. While different strains (isolates) of S. mansoni clearly behave differently in laboratory hosts it is unclear if these patterns are relevant to human infections. Strains from patients with acute schistosomiasis or hepatosplenic disease did not differ in the pathology they produced in mice (Costa \& Katz 1982, Costa et al. 1984) but Thiongo et al. (1997) found differences in egg production and egg passage in the feces of mice infected with different Kenyan strains of $S$. mansoni and felt these might be related to clinical differences in infected humans.

However, a given isolate may produce one pattern of infection (e.g. a higher proportion of eggs in the liver) in mice (Anderson \& Cheever 1972) and a different pattern in monkeys (Powers \& Cheever 1972). Rapid changes in isoenzyme patterns occur during successive generations of newly isolated $S$. mansoni strains in mice so that it is clear that genetic selection may occur rapidly in the laboratory (LoVerde et al. 1985, Bremond et al. 1993). Pinto et al. (1997) recently documented the greater genetic variability in worms from field isolates compared to the LE strain long maintained in the laboratory. Passage in the molluscan host may also result in genetic selection of the worms (Richards \& Shade 1987).

TABLE I

Primate models of Schistosoma mansoni infection

\begin{tabular}{|c|c|c|c|c|}
\hline Species and References & $\begin{array}{l}\text { Development } \\
\text { Early/Late }\end{array}$ & $\begin{array}{l}\text { Fecundity } \\
\text { Early/Late }\end{array}$ & $\begin{array}{c}\text { Fecal egg excretion } \\
\text { Early/Late }\end{array}$ & $\begin{array}{l}\text { Hepatic fibrosis } \\
\text { General/Pipestem }\end{array}$ \\
\hline Chimpanzee $^{1}$ & $\mathrm{~N} / \mathrm{N}$ & $\mathrm{N} / \mathrm{N}$ & $\mathrm{N} / \mathrm{N}$ & $+++/+++$ \\
\hline Baboon $^{2 \mathrm{a}}$ and & $\mathrm{N} / \mathrm{N}$ & $\mathrm{N} / \downarrow$ & $\mathrm{N} / \downarrow$ & $+---/ 0$ \\
\hline Cercopithecus monkey ${ }^{2 b}$ & & & & or $++/++13$ \\
\hline Capuchin $^{3}$ & $\mathrm{~N} / \mathrm{N}$ & $\mathrm{N} / \mathrm{N} ?$ & $\mathrm{~N} / \mathrm{N} ?$ & $+--/ 0$ \\
\hline Rhesus ${ }^{4}$ & $\mathrm{~N} / \downarrow \downarrow \downarrow$ & $\mathrm{N} / \downarrow \downarrow \downarrow$ & $\mathrm{N} / \downarrow \downarrow \downarrow$ & $+--/ 0$ \\
\hline Aotus 5 & $\mathrm{~N} / \mathrm{N}$ & $\mathrm{N} / \mathrm{N}$ & $\mathrm{N} / \mathrm{N}$ & $+/ 0$ \\
\hline Stump tail macaque ${ }^{6}$ & $\mathrm{~N} / \mathrm{N} ?$ & $\mathrm{~N} / \mathrm{N} ?$ & $\mathrm{~N} / \downarrow ?$ & $? / 0$ \\
\hline Cynomolgus 7 & $\mathrm{~N} / \downarrow ?$ & $\mathrm{~N} / \mathrm{N}$ ? & $\mathrm{N} / \downarrow ?$ & $? / 0$ \\
\hline Squirrel monkey ${ }^{8}$ & $\downarrow \downarrow / \downarrow \downarrow$ & $\downarrow \downarrow / \downarrow \downarrow$ & $\downarrow / \downarrow$ & $? / 0$ \\
\hline Marmoset $^{9}$ & $\downarrow / \downarrow$ & $\downarrow \downarrow \downarrow / \downarrow \downarrow \downarrow$ & $0 / 0$ & $+++/ 0$ \\
\hline Tree shrew 10 & $\downarrow \downarrow / \downarrow \downarrow$ & $\downarrow \downarrow / \downarrow \downarrow$ & $0 / 0$ & $? / 0$ \\
\hline Tamarin $^{11}$ & $\mathrm{~N} / \mathrm{N}$ & $\mathrm{N} / \mathrm{N}$ & $\mathrm{N} / \downarrow$ & $+/ 0$ \\
\hline Spider monkey $^{12}$ & $\downarrow / ?$ & $? / ?$ & $? / ?$ & $+/ 0$ \\
\hline
\end{tabular}

N: normal, i.e. similar to a permissive host such as the mouse; $\uparrow \downarrow$ : increased or decreased; ?: unknown; 0: absent.

1: Pan satyrus (Sadun et al. 1970); 2a: Papio anubis (Sadun et al. 1966, Damian et al 1986, 1992, 1996, Mola et al. 1999); 2b: Cercopithecus aethiops (Sadun et al. 1966, Cheever \& Duvall 1974); 3: Cebus apella (Sadun et al. 1966, Barral et al. 1983); 4: Macaca mulatta (Sadun et al. 1966, Cheever \& Powers 1969); 5: Aotus trivirgatus (Erickson et al. 1971); 6: Macaca speciosa (Sadun et al. 1966); 7: Macaca cynomolgus (Sadun et al. 1966); 8: Saimiri sciureus (Sadun et al. 1966); 9: Callithrix sp. (Sadun et al. 1966, Warren \& Simões 1966); 10: Tupaia sp. (Sadun et al. 1966); 11: Saguinus fuscillis (subcutaneous, resistant to percutaneous infection, Portillo \& Damian 1986); 12: Ateles geoffroyi (Sadun et al. 1966); 13: Papio cynocephalus cynocephalus and P. c. anubis (Njenga et al. 1998, Nyindo \& Farah 1999). 
TABLE II

Schistosoma mansoni infection in mammals other than primates and rodents

\begin{tabular}{lccc}
\hline $\begin{array}{l}\text { Species and } \\
\text { References }\end{array}$ & $\begin{array}{c}\text { Development } \\
\text { Early/Late }\end{array}$ & $\begin{array}{c}\text { Fecundity } \\
\text { Early/Late }\end{array}$ & $\begin{array}{c}\text { Hepatic } \\
\text { fibrosis }\end{array}$ \\
\hline Rabbit $^{1}$ & $\downarrow \downarrow \downarrow / \downarrow \downarrow \downarrow \downarrow$ & $\downarrow \downarrow \downarrow / \downarrow \downarrow \downarrow \downarrow$ & + \\
Opossum $^{2}$ & $\downarrow / \downarrow$ & $\mathrm{N} / ?$ & + \\
Armadillo $^{3}$ & $\downarrow / \downarrow$ & $\downarrow / \downarrow$ & \pm \\
Raccoon $^{4}$ & $\downarrow \downarrow / ?$ & $\downarrow / ?$ & \pm \\
Skunk $^{5}$ & $\downarrow \downarrow / ?$ & $\downarrow \downarrow / ?$ & 0 \\
Red fox $^{6}$ & $\mathrm{R}$ & $\mathrm{NA}$ & NA \\
\hline
\end{tabular}

R: resistant to infection; NA: not applicable

1: Sylvilagus floridanus (Lichtenberg et al. 1962, Andrade et al. 1988); 2: Didelphis marsupialis (Lichtenberg et al. 1962); 3: Dasypus novemcinctus (Smith et al. 1988); 4: Procyon lotor (Lichtenberg et al. 1962); 5: Mephitis nigra (Lichtenberg et al. 1962); 6: Vulpes fulva (Lichtenberg et al. 1962).

Numerous other species have been exposed but little or no description of the pathology was noted; e.g. Loos (1964) exposed Erinaceus europaeus, Sorex araneus, Sciurus vulgaris, Glis glis, Chlethrionomys glareolus, Microtus avalis, Ondatra zibethica, Micromys minutus, Apodemus flavicollis, Rattus ratus, Rattus norvegicus and Apodeumus sylvaticus. Stirewalt et al. (1951) exposed cats, dogs, three varieties of rabbits, cotton rats and albino rats (Sigmodon hispidus hispidus and Mus norvegiucus albinus) in addition to mice and hamsters. Kuntz and Malakatis (1955) exposed Mus musculus pratextus, Rattus rattus, Arvicanthus niloticus, Acomys cahirinus, Gerbilus pyramicum, Jaculul jaculus, Meriones s. shawi, Psammomys o. obesus, Nesokia indica suilla, Hemiechinus auritus aegypticus, Mustela nivalis subpalmata, Herspestes i. ichneumon and Vulpes $v$. aegyptiaca. Torrealba et al. (1958) exposed Didelphis marsupialis, Calluromys trinitatis venezulae, Cebus nigrivittatus, Cerdocyon thous, Herpalurus jagarundi, Sciurus granatenis griseogena, Echymis semivillosus punctatus, Dasyprocta rubrata, Sylvilagus floridanus valenciae, Hydrochoerus hydrochoeri, Cuniculus paca and Pecari tajacu torvus.

\section{ACUTE TOXEMIC SCHISTOSOMIASIS}

Humans infected for the first time with $S$. mansoni often develop an acute disease characterized by fever, malaise, diarrhea, intense eosinophilia and occasionally allergic manifestations such as asthma or angioedema (hives). Symptoms may appear before the onset of oviposition and are accentuated after oviposition. Acute disease is virtually unknown in residents of endemic areas but is frequent in outsiders exposed for the first time. Acute toxemic schistosomiasis is associated with high levels of immune complexes and with a vigorous cellular response to schistosome antigens (Hiatt et al. 1980). Symptoms, signs and immune reactivity decrease over a period of months while the infection continues unabated. An acute toxemic phase is obvious in many animal models judging from the appearance of the animals and from an initial vigorous cellular immunity and high eosinophilia. As the infection becomes "chronic", at 10-20 wks, the appearance of the animals improves and the cellular response to antigen is downregulated while egg laying by the parasite continues unchanged (Tawfik et al. 1986, Damian et al.1992). Particular efforts to study the toxemic phase have been made in baboons, which exhibit fever as well as the other features noted in mice and other animal models (Damian et al. 1992, 1996). It is unclear, however, how to relate the experimental acute disease to that in humans. The cytokine patterns which may be related to the fever, malaise and other symptoms and signs of the acute phase in baboons included TNF- $\alpha$, IL-1 and IL-6 (Damian et al. 1996), findings remarkably similar to those later reported in humans (Jesus et al. 2002).

Decreased levels of corticotropin-releasing hormone, adrenocorticotropic hormone and dehydroepiandrosterone were reported by Morales-Montor et al. (2001) in acutely infected baboons and mice but not in rechallenged chronically infected baboons. In baboons, but not mice, the lower hormone levels correlated with unmodulated granulomas.

\section{THE FORMATION OF CIRCUMOVAL GRANULOMAS AND MODULATION OF GRANULOMA SIZE}

Studies in infected mice often give different results than those obtained from intravenous injection of eggs. A general overview will be presented here and differences between the lung model and the use of infected mice will be detailed later.

It has long been clear that T helper cells (CD4+ T cells) are instrumental for the formation of granulomas around S. mansoni eggs (Mathew \& Boros 1986) and that CD8+

\section{TABLE III}

Schistosoma mansoni infection in rodents other than mice

\begin{tabular}{lccc}
\hline Species & $\begin{array}{c}\text { Development } \\
\text { Early/Late }\end{array}$ & $\begin{array}{c}\text { Fecundity } \\
\text { Early/Late }\end{array}$ & $\begin{array}{c}\text { Hepatic fibrosis } \\
\text { (mice=+++) }\end{array}$ \\
\hline Woodchuck $^{1}$ & $\mathrm{~N} / \downarrow \downarrow \downarrow$ & $\mathrm{N} / \downarrow \downarrow \downarrow$ & + \\
Calomys $^{2}$ & $\mathrm{~N} / ?$ & $\mathrm{~N} / \mathrm{N}$ & \pm \\
Mastomys $^{3}$ & $\mathrm{~N} / \mathrm{N}$ & $\mathrm{N} / \mathrm{N}$ & + \\
Rat-lab $^{4}$ & $\mathrm{I} / \mathrm{sc}$ & $\downarrow \downarrow \downarrow / \mathrm{sc}$ & \pm \\
Rattus rattus $^{5}$ & $>>$ lab rat & $>>$ lab rat & $?$ \\
Hamster $^{6}$ & $\mathrm{~N} / \mathrm{N}$ & $\mathrm{N} / \mathrm{N}$ & \pm \\
Gerbil $^{7}$ & $\mathrm{~N} / \mathrm{N}$ & $\mathrm{N} / \mathrm{N}$ & \pm \\
Gray squirrel $^{8}$ & $\mathrm{~N} / ?$ & $\mathrm{~N} / ?$ & + \\
Chipmunk $^{9}$ & $\downarrow / ?$ & $\downarrow \downarrow / ?$ & \pm \\
Nutria $^{10}$ & $-/ ?$ & $\downarrow \downarrow / ?$ & \pm \\
Meadow vole $^{11}$ & $\downarrow / ?$ & $\downarrow \downarrow / ?$ & \pm \\
Muskrat $^{12}$ & $\mathrm{R}$ & $\mathrm{R}$ & $\mathrm{R}$ \\
Guinea pig $^{13}$ & $\downarrow / \downarrow$ & $? / ?$ & \pm \\
Agouti $^{14}$ & $\mathrm{~N} / ?$ & $\mathrm{~N} / ?$ & + \\
\hline R: resistant & in &
\end{tabular}

R: resistant to infection; $\uparrow \downarrow$ : increased or decreased; \pm : slight change; N: normal; ?: insufficient data; sc: self cure, i.e. adult worms are killed.

1: Marmota monax (Anderson et al. 1991, Andrade et al. 2001); 2: Calomys callosus (Lenzi et al. 1995); 3: Mastomys coucha (Cheever 1965a, b); 4: (Phillips et al 1987); 5: (Denoya et al 1997, Cêtre et al. 1999); 6: Mesocricetus auratus (Cheever 1965a, b; 7: Pachyuromys duprasi natronensis (Cheever 1965a, b; 8: Sciurus carolinensis (Lichtenberg et al. 1962); 9: Tamias striatus (Lichtenberg et al. 1962); 10: Myocaster coypus (Lichtenberg et al. 1962); 11: Microtus pennsylvanicus (Lichtenberg et al. 1962); 12: Ondatra zibethicus (Lichtenberg et al. 1962); 13: (Hsu et al. 1973, Pearce \& McLaren 1983); 14: Dasyprocta aguti (Price 1953). 
T cells appear to be important for downregulation of granuloma size in chronic infections (Chensue \& Boros 1979, Henderson et al. 1992), but antibody is necessary in addition to downregulated T cells (Jankovic et al. 1998).

In acute infections ( $8 \mathrm{wk}$ ) regulation of granuloma size seems to differ fundamentally from downregulation in chronic infection. Thus in acute infection granuloma size seems controlled principally by $\mathrm{T}$ cells and volume is decreased by IL-10 (Flores Villanueva et al. 1996), increased in the absence of Il-10 (Wynn et al. 1998) and increased by administration of cyclophosphamide or cymetidine (Weinstock \& Boros 1981, Weinstock et al. 1983). Cyclophosphamide also increased granuloma size in chronic infections and one needs to postulate that the effect on $\mathrm{T}$ cells can partially overcome the effects of immunoglobulins (Colley et al. 1979, Weinstock et al. 1983). Antibody has a significant but modest effect in acute infections (Jankovic et al. 1998).

Delayed type hypersensitivity (DTH) is commonly taken to be indicative of a Th1-type cellular reaction, although there are several instances in which contact hypersensitivity etc. have been shown to be predominantly a Th2-type response (Assherson et al. 1996). The reaction to schistosome eggs is a cell-mediated hypersensitivity reaction which has usually been considered to be a DTH reaction. We think that the evidence indicates that the reaction to schistosome eggs is predominantly Th2 and propose that the schistosome granuloma be considered as a type-2 DTH, although it is clear that the granuloma can begin as a Th1-type response and can also later be manipulated toward Th1. Rakasz et al (1998) found that granulomas contained numerous activated Th1 and Th0 cells but that these were under tight control.

Lenzi et al. (1998) have given a detailed morphogenic and biomechanical description of granuloma development and involution and have detailed the spatial deployment of collagen fibers within the granulomas (Lenzi et al. 1999).

\section{The Role of Cytokines in Granuloma Formation and Downregulation (See Tables IV-VI)}

Several comprehensive reviews dealing with this subject have been published recently (Lukacs \& Boros 1993, Wynn \& Cheever 1995, Cheever \& Yap 1997, Cheever et al. 1998, Fallon 2000) and the discussion here will be oriented toward the models described. Adhesion molecules such as ICAM-1 are presumably important for circulating cells to reach the site of the granuloma (Langley \& Boros 1995, Jacobs et al. 1997b) and adhesins are upregulated in acute and chronic murine infections.

The earliest hepatic granulomas form in a Th1 environment with downregulation of Th1 and upregulation of Th2 responses 6 wk after infection (Todt et al. 2000). This sequence is similar to that seen after injecting eggs into the lungs (Wynn et al. 1993). The intense blood and tissue eosinophilia and high IgE antibody levels associated with schistosome infections suggest a Th2-type reaction. Treatment of injected or infected mice with IFN- $\gamma$ results in decreased granuloma size and hepatic fibrosis (Czaja et al. 1989a) while chronically infected (immunologically downregulated) mice treated with IL-4 make larger granulomas than do untreated animals (Yamashita \& Boros 1992).
IL-4 and IL-13 are largely compensate for each other for formation of hepatic granulomas in infected mice. Thus only minute granulomas are formed when both are suppressed, as in IL-4 receptor ko mice (Jankovic et al. 1999) or IL-4 ko mice in which IL-13 action is suppressed (Chiramonte et al. 1999b). Kaplan et al. (1998) found that Stat6 knockout mice mounted a minimal $\mathrm{Th} 2$ response and formed small granulomas. Stat 4 deficient mice showed a minimal Th1 response but normal hepatic granulomas. Wynn et al. (1995a) found that immunization with SEA and IL-12 produced immune deviation toward Th-1 type reactions with reduction of granuloma sized. All of these effects are consistent with the concept of the granuloma as a Th2 dominant reaction, but under some conditions Th1 granulomatous responses may be predominant and damaging (Stadecker \& Hernandez 1998, Chen \& Boros 1999, 2001, Hoffmann et al. 2000, Rutitzkky et al. 2001). cDNA microarrays are a powerful tool for examining arrays of activated genes in schistosome infected-mice with Th1 and Th2 type mediated reactions and led to recognition of the importance of neutrophils in hepatic lesions of wild type and immune deviated mice (Hoffmann et al. 2001).

TABLE IV

Murine models of Schistosoma mansoni infection

\begin{tabular}{|c|c|c|}
\hline $\begin{array}{l}\text { Type of mouse } \\
\text { and References }\end{array}$ & $\begin{array}{c}\text { Hepatic granuloma size } \\
\text { Early/Late }\end{array}$ & Hepatic fibrosis \\
\hline $\begin{array}{l}\text { Outbred } \\
\text { Germfree }^{\text {1a }} \\
\text { Inbred }^{2} \\
\text { Biozzi }^{2 a}\end{array}$ & $\begin{array}{c}\mathrm{N} / \downarrow \\
\downarrow ? / ? \\
\mathrm{~V} \dagger / \downarrow \\
\mathrm{HIII}>\mathrm{LIII}\end{array}$ & $\begin{array}{c}+++ \\
\downarrow \\
+ \text { to }+++ \\
\text { HIII = LIII }\end{array}$ \\
\hline $\begin{array}{l}\text { Immuno-deficient } \\
\text { Nude }^{3 \mathrm{a}} \\
\mathrm{SCID}^{3 \mathrm{~b}} \\
\mathrm{~W} / \mathrm{Wv}^{3 \mathrm{c}} \\
\mathrm{bg} / \mathrm{bg}^{3 \mathrm{~d}} \\
\mathrm{XID}{ }^{3 \mathrm{e}}\end{array}$ & $\begin{array}{l}\downarrow / \downarrow \\
\downarrow / \downarrow \\
=/ ? \\
=/= \\
\downarrow /=\end{array}$ & $\begin{array}{l} \pm \\
\pm \\
= \\
= \\
=\end{array}$ \\
\hline $\begin{array}{l}\text { Transgenic } \\
\text { IL-7 }{ }_{\text {gutaneous }} \\
\text { IL-9 } \\
\text { TGF- } \beta 1^{4 a}\end{array}$ & $\begin{array}{c}? \\
= \\
=/ ?\end{array}$ & $\begin{array}{l}\uparrow \\
= \\
\uparrow\end{array}$ \\
\hline 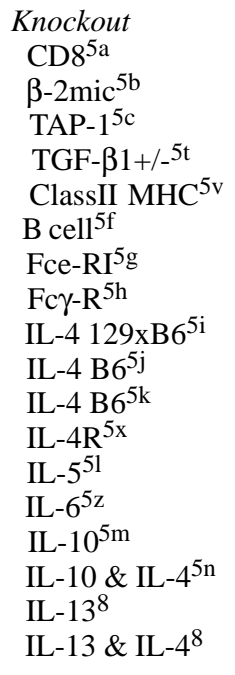 & $\begin{array}{c}=I= \\
=I= \\
=I= \\
=/= \\
\downarrow \downarrow \downarrow / / ? \\
\uparrow / \uparrow \uparrow \\
\uparrow / ? \\
\uparrow / \uparrow \\
=/= \\
\downarrow / ? \\
=/ ? \\
\downarrow \downarrow \downarrow / ? \\
=I= \\
=/ ? \\
\uparrow /= \\
=/ ? \\
= \\
\downarrow \downarrow \downarrow \downarrow\end{array}$ & $\begin{array}{c}= \\
= \\
= \\
? \\
\downarrow \downarrow \\
\uparrow \uparrow \\
\uparrow \\
\uparrow \\
= \\
= \\
? \\
\downarrow \downarrow \downarrow \\
\pm \uparrow \\
? \\
= \\
\downarrow \\
\downarrow \downarrow \downarrow \\
\downarrow \downarrow \downarrow\end{array}$ \\
\hline
\end{tabular}




\begin{tabular}{|c|c|c|}
\hline $\begin{array}{l}\text { Type of mouse } \\
\text { and References }\end{array}$ & $\begin{array}{c}\text { Hepatic granuloma size } \\
\text { Early/Late }\end{array}$ & Hepatic fibrosis \\
\hline $\mathrm{IFN}^{50}$ & $=/=$ & $=$ \\
\hline IFN-R ${ }^{5 p}$ & $=$ or $\downarrow /$ ? & $?$ \\
\hline IL- $6^{5 \mathrm{u}}$ & $=/ ?$ & $?$ \\
\hline Il- $7^{7}$ & $\downarrow \downarrow / ?$ & $\downarrow \downarrow \downarrow$ \\
\hline Stat $4^{5 w}$ & $=/$ ? & $=$ \\
\hline Stat $6^{5 w}$ & $\downarrow \downarrow \downarrow$ & $\downarrow \bar{\downarrow} \downarrow$ \\
\hline Substance $P-R^{5 y}$ & $\downarrow / ?$ & $?$ \\
\hline $5-\mathrm{LO}^{5 \mathrm{r}}$ & $\downarrow / ?$ & $?$ \\
\hline $12-\mathrm{LO}^{5 \mathrm{r}}$ & $=1 ?$ & $?$ \\
\hline $\operatorname{IgE}^{5 s}$ & $\downarrow / ?$ & $=$ \\
\hline MIP- $1 \alpha R^{5 d}$ & $=/ ?$ & $=$ \\
\hline B7- $1^{-/-5 q}$ & $=$ & $?$ \\
\hline B7- $2^{-/-5 q}$ & $=$ & $=$ \\
\hline B7-1/2-/-5q & $\downarrow$ & $=$ \\
\hline TIMP- 110 & $=$ & $\bar{z}$ \\
\hline TIMP-2 $2^{10}$ & $=$ & $=$ \\
\hline $\mathrm{TNFR}^{5 \mathrm{e}}$ & $=/ ?$ & $=/ ?$ \\
\hline CD154 & $\downarrow / ?$ & $?$ \\
\hline
\end{tabular}

$\mathrm{V} \dagger$ : variable between strains; $\uparrow \downarrow$ : increased, decreased or unchanged compared to appropriate control mice.

1a: Viera \& Moraes-Santos (1987); 2: Cheever et al. (1987); 2a: Biozzi high (HIII) and low (LIII) responder mice (Blum \& Cioli 1978, Catapani et al. 1994); 3a: nude athymic mice lacking T cells (Cheever et al. 1993); 3b: mice with severe combined immunodeficiency lacking T \& B cells (Amiri et al. 1992, Cheever et al. 1999); 3c: mast cell deficient mice (Cheever et al. 1987); 3d: Cheever et al. (1987); 3e: Gaubert et al. (1999); 5a: Yap et al. (1977); 5b: $\beta-2$ microglobulin deficient mice (Yap et al. 1997, Hernandez et al.1997b); 5c: mice unable to process class 1 antigens (Yap et al. 1977); 5d: receptor for macrophage Inflammatory Protein-1 $\alpha$ [CCR-III] (Gao et al. 1997); 5e: mice lacking both TNF- $\alpha$ receptors (Yap et al. unpublished); $5 \mathrm{f}: \mu$ MT mice (Jankovic et al. 1998, Ferru et al. 1998) JHD B-less mice had normal granulomas at 8 wk (Hernandez et al. 1997a); 5g: Jankovic et al. (1997); 5h: Jankovic et al. (1998); 5i: IL-4 ko mice from cross of 129J and C57BL/6 mice (Pearce et al. 1996); 5j: IL-4 ko mice bred back to the C57BL/6 background (Rosa Brunet et al. 1997); 5k: IL-4 ko mice formed using C57BL/6 germline only (Metwali et al. 1996); 51: Rosa Brunet et al. (1999a); 5m: Wynn et al. (1998); 5n: Wynn et al. (1998); 5o: Amiri et al. (1994, Yap et al. unpublished); 5p: (Akihani et al. 1996, Rezende et al. 1997a, Oliveira et al. 2000); 5q: Hernandez et al. (1999); 5r: 5 lipoxegenase, 12-lipoxygenase (Secor et al. 1998); 5s: King et al. (1997); 5t: Frazier-Jessen et al. (unpublished); 5u: Blum et al. (1997); 5v: Hernandez et al. (1997b); 5w: Kaplan et al. (1998) Stat4- deficient mice make a deficient Th1-type reaction and Stat6-deficient mice a deficient Th2-type reaction; 5x: Jankovic et al. (1999); 5y: substance P receptor (Blum et al. 1999); 5z: Blum et al. (1998); 6: Angyalosi et al. (1998); 7: Wolowczuk et al. (1999); 8: Fallon et al. (2000b); 8: Fallon et al. (2000c); 9: Roye et al. (2001); 10: Vaillant et al. (2001).

In chronic infections (20 wk) Th2 responses are blunted (Grzych et al. 1991, Henderson et al. 1992, Chensue et al. 1992) and Borojovic (1992) regards the chronic phase of murine schistosomiasis as predominantly Th1 mediated, largely on the basis of increasing ratio of $\operatorname{IgG} 2 \mathrm{a}$ to IgG1 and decreasing eosinophil and IgE levels in chronically infected mice. IFN- $\gamma$, IL-4 and IL-10 exert cross-regulatory effects on the Th1-Th2 balance as IL-4 drives the reaction toward Th2, IFN- $\gamma$ toward Th1 and IL-10 may inhibit either trend depending on the circumstances (Chensue et al. 1994a, b, Jankovic \& Sher 1996, Wynn et al. 1997, 1998, Boros \& Whitfield 1998). IL-10 ko (knockout) mice also formed very large granulomas $8 \mathrm{wk}$ after infection but subsequently downregulated granuloma size (Wynn et al. 1998).

IL-5 does not seem to be directly involved in mediating granuloma size or fibrosis. Anti-IL-5 treated mice lacked eosinophils but granuloma size and hepatic fibrosis were virtually unaffected in both acute (Sher et al. 1990) and chronic (Cheever et al. 1992c) infections and the pathology was not greatly changed in IL-5 ko mice (Rosa Brunet et al. 1999a). Rumbley et al. (1999), however, note that eosinophils form the majority of cytokine producing cells in the granuloma and are the dominant source of IL-4.

\section{TABLE V}

Infected-mice treated with cytokines or antibodies against cytokines

\begin{tabular}{|c|c|c|}
\hline Cytokine or antibody & $\begin{array}{c}\text { Hepatic granuloma size } \\
\text { Early/Late }\end{array}$ & $\begin{array}{l}\text { Hepatic } \\
\text { fibrosis }\end{array}$ \\
\hline \multicolumn{3}{|c|}{$\mathrm{IFN}-\gamma^{1}$} \\
\hline anti-IFN- $\gamma^{2}$ & $=1=$ & $=$ \\
\hline IL- $12^{12,20}$ & $\pm \downarrow / ?$ & \pm \\
\hline IL-12 +anti-IL-4+anti & $10^{20}$ & $\downarrow \downarrow \downarrow$ \\
\hline TNF- $\alpha^{3}$ & $\uparrow / \uparrow$ & $\uparrow$ \\
\hline anti-TNF- $\alpha^{4}$ & $\downarrow / ?$ & $?$ \\
\hline anti-NK1.1 $1^{19}$ & $? / ?$ & $\dot{\uparrow}$ \\
\hline $\mathrm{IL}-2^{5}$ & $\uparrow / \uparrow$ & $?$ \\
\hline anti-IL-2 6 & \pm or $\downarrow / \downarrow$ & $\downarrow \dot{\downarrow}$ \\
\hline IL-4 ${ }^{7}$ & $\uparrow / \uparrow$ & $?$ \\
\hline anti-IL-4 ${ }^{8}$ & $=$ or $\downarrow / \downarrow$ & $\downarrow \downarrow$ \\
\hline anti-IL-5 ${ }^{9}$ & $=/=$ & $=$ \\
\hline IL- $10 / \mathrm{Fc}^{10}$ & $\downarrow / ?$ & $?$ \\
\hline \multicolumn{3}{|l|}{ anti-IL-10 $0^{11}$} \\
\hline $\mathrm{PGE}_{1} 14$ & $\downarrow / ?$ & $?$ \\
\hline $\mathrm{PGF}_{2 \alpha} 15$ & $\downarrow / ?$ & ? \\
\hline NK-1RA ${ }^{2}{ }^{2}$ & $=/ ?$ & $?$ \\
\hline SOM analogue ${ }^{17}$ & $\uparrow / ?$ & ? or $\downarrow$ \\
\hline Cimetidine $e^{18}$ & $\uparrow / \uparrow$ & $?$ \\
\hline Diphenhydramine $^{18}$ & $\downarrow / \downarrow$ & $?$ \\
\hline
\end{tabular}

$\uparrow, \downarrow$ : increase, decrease or no change; ?: unknown; \pm : slight change.

1: Czaja et al. (1989a, b); 2: (Sher et al. 1990, Cheever et al. 1992c); 3: SCID mice, Amiri et al. (1992); chronically infected mice, Joseph \& Boros (1993); 4: Joseph \& Boros (1993); 5: Mathew et al. (1990); 6: Cheever et al. (1992); 7: Yamashita \& Boros (1992); 8: Yamashita \& Boros (1992), Cheever et al. (1994); 9: acute (Sher et al. 1990), chronic (Cheever et al. 1992c); 10: IL$10 / \mathrm{Fc}$ fusion protein, competes with IL-10 (Flores-Villanueva et al. 1996, also see Verwaerde et al. 1999); 11: 12: (IP Oswald et al. unpublished) IL-12 was generally ineffective in reversing the Th2 response in $S$. mansoni-infected mice once infection has begun; 13: Boros \& Whitfield (1998); 14: Prostaglandin $\mathrm{E}_{1}$ (Chensue et al. 1986); 15: Prostaglandin $\mathrm{F}_{2 \alpha}$ (Chensue et al. 1986); 16: antagonist for NK-1 receptor (for substance P \& other tachykinins), (Blum et al. 1993); 17: (Blum et al. 1992, Mansy et al. 98), mice were treated with octreotide, a somatostatin (SOM) analogue which competes with SOM; 18: antihistamines, Cimetidine blocks $\mathrm{H}_{1}$ receptors and diphenhydramine $\mathrm{H}_{2}$ receptors (Weinstock et al. 1983); 19: antibody to natural killer cells (Asseman et al. 1996); 20: Boros \& Whitfield (1999). 
The use of $\mathrm{T}$ cell lines and clones would seem to be a definitive way of resolving the relative importance of Th1 and Th2 cells. However granulomas are induced by transfer of Th0, Th1 and Th2 cells specific for SEA (Chickunguwo et al. 1991, Zhu et al. 1994, Jankovic et al. unpublished).

The downregulation of granuloma size has often been regarded as an effect of CD8+ suppressor cells (Chensue $\&$ Boros 1979, Green \& Colley 1981) which one might expect to be mediated at least in part by IFN- $\gamma$. Normal downregulation was found in ko mice unable to make IFN$\gamma$, in CD8 ko mice, in $\beta-2$ microglobulin ko mice (also virtually unable to produce CD8+ cells) and in TAP1 ko mice which are unable to process antigen in the context of class I (Hernandez et al. 1997b, Yap et al. 1997). It is unclear how these findings can be reconciled with the studies implicating CD8+ cells in downregulation of granuloma size. Rumbley et al. $(1998,2001)$ hypothesize that selective apoptosis of sensitized lymphocytes within the granulomas contributes to immunoregulation (Rumbley et al. 1998, 2001, Lundy et al. 2001, Lundy \& Boros 2002).

Infected mice rendered $\mathrm{B}$ cell deficient by treatment with anti- $\mu$ antiserum (Cheever et al. 1985) or by genetic manipulation (Jankovic et al. 1998, Ferru et al. 1998) ( $\mu$ MT ko mice) did not modulate granuloma size or hepatic fibrosis and showed increased granuloma size and fibrosis in acute $(8 \mathrm{wk})$ and chronic infections. T cell responses to antigen, however, were downregulated normally in chronically infected $\mu \mathrm{MT}$ ko mice. Another type of B cell ko mouse (JHD B-less) showed no difference in granuloma size from controls $8 \mathrm{wk}$ after infection (Hernandez et al. 1997a) but chronic infections were not examined. Mice lacking the $\mathrm{Fc}$ receptor also do not modulate granuloma size normally, indicating that the effect of antibody in modulation is directed through the Fc receptor (Jankovic et al. 1998). This result is consistent with the reports of downregulation of in vitro granuloma size by immune complexes (Goes et al. 1991,1994, Rezende et al. 1997b, c).

SCID mice show almost no reaction to $S$. mansoni eggs but after injection with recombinant TNF- $\alpha$ formed granulomas around S. mansoni eggs (Amiri et al. 1992) and infected, immunologically intact mice treated with antiTNF- $\alpha$ formed granulomas reduced in size (Joseph \& Boros 1993). Administration of recombinant murine TNF- $\alpha$ to mice with chronic $S$. mansoni infection restored granuloma size to that seen in acutely infected animals (Joseph $\&$ Boros 1993). Nevertheless mice lacking both the p55 and p 75 chains of the TNF- $\alpha$ receptor formed normal granulomas in $8 \mathrm{wk}$ infections (Yap et al. unpublished). Cheever et al. (1999) were unable to affect granulomas in infected SCID mice by injection of TNF- $\alpha$.

Flores Villanueva et al. (1994) consider the granuloma to be a Th1-type response and attribute downregulation to anergy. Treatment of acutely infected animals with IL$10 \mathrm{Fc}$ fusion protein decreased the size of granulomas in acute infection while diminishing levels of Th1 cytokines (IFN- $\gamma$ and IL-2) and augmenting levels of Th2 cytokines (Il-4 and IL-10) (Flores Villanueva et al. 1996). Chen and Boros $(1998,1999)$ produced "Th1" or "Th2" granulomas to egg antigen epitopes p38 or P4 depending on the adjuvant used in mice of the $\mathrm{H} 2 \mathrm{k}$ haplotype.
IL-4 knockout mice exhibited increased Th1-like responses and markedly diminished Th2 responses but granuloma size and hepatic fibrosis during infection were equivalent to those in intact controls (Pearce et al. 1996, Rosa Brunet et al. 1997). However, T cell responses were more generally affected in IL-4 ko mice (PedrasVasconcelos et al. 2001). Metwali et al. (1996) found granuloma size to be diminished in IL-4 ko mice but gave a different interpretation to cytokine patterns similar to those reported by Pearce et al. (1996) and Chiramonte et al. (1999b) found enlarged granulomas but decreased fibrosis in IL-4 ko mice. Other experiments in various strains of IL-4 ko mice have given discrepant results which we cannot yet interpret (Cheever et al. 1998, Jankovic et al. unpublished).

Weinstock and his colleagues $(1992,1998)$ have extensively investigated the role of angiotensin converting enzyme and neuropeptides in the formation and modulation of schistosome granulomas (Tables IV-VI). Chemokine expression has been examined broadly by Park et al. (2001) and Qiu et al. (2001).

\section{TABLE VI}

Use of cytokine or anti-cytokine treatments and knockout (ko) mice using the lung model in experimental murine schistosomiasis

\begin{tabular}{|c|c|}
\hline Treatment & Effect on granuloma size \\
\hline IFN- $\gamma^{1 \mathrm{a}}$ & $\downarrow$ \\
\hline anti-IFN- $\gamma^{1 b}$ & $\uparrow$ \\
\hline IFN ko $1 \mathrm{c}^{1}$ & $\uparrow$ \\
\hline IFNR $\mathrm{ko}^{1 \mathrm{~d}}$ & $\uparrow$ \\
\hline TNF- $\alpha^{2 \mathrm{a}}$ & $\uparrow$ \\
\hline anti-TNF- $\alpha^{2 b}$ & $\pm \downarrow$ \\
\hline anti-B7-1 ${ }^{2 c}$ & $=$ \\
\hline anti-B7-2 $2 \mathrm{c}$ & $\downarrow \downarrow$ \\
\hline anti-IL-2 $2^{4}$ & $\downarrow \downarrow \downarrow$ \\
\hline IL-4 $4^{5 a}$ & $\uparrow$ \\
\hline $\mathrm{IL}-4 \mathrm{ko}^{5 \mathrm{~b}}$ & $\downarrow$ \\
\hline anti-IL-4 ${ }^{5 c}$ & $\downarrow \downarrow \downarrow$ \\
\hline anti-IL-6 6 & $=$ \\
\hline IL- $10^{7 \mathrm{a}}$ & $\downarrow$ \\
\hline anti-IL-10 $7 \mathrm{~b}$ & $=$ \\
\hline IL-10 $\mathrm{ko}^{7 \mathrm{c}}$ & $\downarrow$ \\
\hline IL-4 \& IL-10ko ${ }^{7 d}$ & $\downarrow \downarrow \downarrow$ \\
\hline IL- $12^{8 \mathrm{a}}$ & $\downarrow$ \\
\hline anti-IL- $12^{8 b}$ & $\uparrow$ \\
\hline $\mathrm{IL}-4+\mathrm{IL}-13 \mathrm{ko}^{3}$ & $\downarrow \downarrow \downarrow$ \\
\hline IL-13R $\alpha 2 \mathrm{Fc}^{21}$ & $\downarrow \downarrow$ \\
\hline IL-13 transgenic mouse ${ }^{24}$ & $\downarrow$ \\
\hline Stat4 ko $18^{\circ}$ & $\downarrow \downarrow \downarrow$ \\
\hline Stat6 ko ${ }^{18}$ & $\downarrow$ \\
\hline$\beta 2 \mathrm{~m} \mathrm{ko}^{9}$ & $=$ \\
\hline Anti-ICAM- $1^{10}$ & $\downarrow$ \\
\hline Anti-MCP 11 & $\downarrow /=$ \\
\hline Anti-MIP- $1 \alpha^{12 a}$ & $\downarrow /=$ \\
\hline CCRI--MIP- $1 \alpha \mathrm{R} \mathrm{ko}^{12 \mathrm{~b}}$ & $\downarrow$ \\
\hline CCRII--MCP-1R ko ${ }^{12 \mathrm{c}}$ & $\pm \downarrow$ \\
\hline INOS ko $\mathrm{ko}^{17}$ & $\pm \downarrow$ \\
\hline $\mathrm{B}$ cell ko ${ }^{18}$ & $=$ \\
\hline TGF $\beta-1 \mathrm{ko}^{13 \mathrm{a}}$ & $\pm \downarrow$ \\
\hline TGF $\beta-1 \operatorname{tg}^{13 b}$ & $\pm \uparrow$ \\
\hline
\end{tabular}




\begin{tabular}{lc}
\hline Treatment & Effect on granuloma size \\
\hline Anti-NK1.1 or anti-AsialoGM $_{1} 14$ & $\uparrow$ \\
PGE $_{1} 15 \mathrm{a}$ & $\downarrow$ \\
PGF $_{2 \alpha}$ 15b & $\downarrow$ \\
p47 $^{\text {hox- }-22}$ & $=$ \\
NK-1RA $^{16}$ & $\downarrow$ \\
Osteopontin ko $^{23}$ & $\downarrow$ \\
Rantes $^{20}$ & $\downarrow$ \\
\hline
\end{tabular}

$\uparrow, \downarrow$ : increased, decreased or unchanged; \pm : slight change; $\{\mathrm{N}$ : naive mouse; $S$ : sensitized mouse; I: infected mouse; E: eggs injected; B: antigen coated beads injected $\}$.

1a: $\{$ I,E $\}$ (Lukacs \& Boros 1993); 1b: $\{$ I,B $\}$ (Lukacs \& Boros 1993), \{S,E $\}$ (Chensue et al. 1994, \{S,E $\} 1995 \mathrm{c}$ ); $\{\mathrm{S}, \mathrm{E}\} 1$ 1996; \{N,E\} (Wynn et al. 1994). 1c: (Wynn et al. 1995b); 1d: $\{\mathrm{N}, \mathrm{E}\}$ (Mountford et al. 1999); 2a: \{I,E\} (Joseph \& Boros, 1993); 2b: $\{$ S,B $\}$ (Chensue et al. 1994b, 1995c, 1996); 3: \{N,E\} (McKenzi et al. 1999); 4: \{I,B $\}$ (Lukacs \& Boros 1993, \{N,E $\}$ Wynn et al. 1993); 5a: (Yamashita \& Boros 1992, \{I,B \} Lukacs \& Boros 1993, \{N,E\} Wynn et al. 1993, \{N,E $\}$ Eltoum et al. 1995); 5b: \{I.E $\}$ (Pearce et al. 1996, \{S,E $\}$ Wynn et al. 199 7); 5c: $\{\mathrm{S}, \mathrm{E}\}$ (Chensue et al. 1992, \{S,E\}, 1994, Wynn et al. 1993, Ruth et al. 2000) 6: $\{$ N,E $\}$ (Cheever et al. unpublished); 7a: recombinant IL-10, \{I,E $\}$ (Flores-Villanueva et al. 1996); 7b: antibody against IL-10, \{N,E\} (Wynn et al. 1994, \{S,E\} Chensue et al. 1994, Chensue et al. 1995c); 7c: IL-10 ko mouse $\{$ N,E;S,E $\}$ (Wynn et al. 1997); 7d: ko for IL-10 and IL-4\{N,E\} (Wynn et al. 1997); 8a: \{S,E\} (Wynn et al. 1994); 8b: \{N,E\} (Wynn et al. 1994); 9: $\beta 2-$ microglobulin ko mice, (Brown et al. 1966); 10: antibody against intracellular adhesion factor 1, \{N,B $\}$ (Lukacs et al. 1994); 11: anti-macrophage chemotactic protein, $\{\mathrm{S}, \mathrm{B}-$-no effect with $\mathrm{N}, \mathrm{B}\}$ (Chensue et al. 1995b, \{S,B $\}$ 1996); 12a: anti-macrophage inflammatory protein $1 \alpha ;\{\mathrm{N}, \mathrm{E}=\downarrow \& \mathrm{~S}, \mathrm{E}=\downarrow$ ) (Lukacs et al. 1993, $\{\mathrm{S}, \mathrm{B}=0\}$ Chensue et al. 1996); 12b: $\{\mathrm{N}, \mathrm{E} ; \mathrm{SE}\} \mathrm{CCR} 1 \mathrm{ko}$ (Gao et al 1997); 12c: CCR2 (Warmington et al. 1999); 13a: ko for TGF $\beta 1$ gene, (Wahl et al. 1997); 13b: mice transgenic for TGFB1 gene, (Wahl et al. 1997); 14: \{N,E\} (Wynn et al. 1994). Both antibodies act against NK cells. 15a: Prostaglandin $\mathrm{E}_{1}$. $\{\mathrm{I}, \mathrm{E}\}$ (Chensue et al. 1986). 15b: Prostaglandin $\mathrm{F}_{2 \alpha},\{\mathrm{I}, \mathrm{E}\}$ (Chensue et al. 1986). 16: antagonist for NK-1 receptor (for substance $P$ and other tachykinins), $\{$ I,E $\}$ (Blum et al. 1993); 17: ko for inducible nitric oxide synthase $\{\mathrm{S}, \mathrm{E}\}$ (Jankovic et al. unpublished); 18: \{N,E $\}$ (Epstein et al. 1995); 19: \{N/S, E $\}$ (Kaplan et al. 1998); 20: $\{\mathrm{N}, \mathrm{B}\}$ (Chensue et al 1999); 21: $\{\mathrm{S}, \mathrm{E}\}$ (Chiramonte et al 1999a); 22: p47 phox-/-, model for chronic granulomatous disease (Segal et al. 1999); 23: $\{$ N,E $\}$ (O'Regan et al. 2001); 24: $\{$ N,B $\}$ (Hu et al. 2001).

\section{Role of Murine Host Genotype on Immune Reactivity, Granuloma Size and Hepatic Fibrosis}

Claas and Deelder (1979) found C3H/Sn $\left(\mathrm{H}-2^{\mathrm{k}}\right)$ mice had lower mortality, antibody titers and DTH (ear swelling) than did C3H.B10 $\left(\mathrm{H}-2^{b}\right)$ mice but worm numbers and cell proliferation in vitro did not differ. The differences extended to the I-region of the H-2 complex and B10.A(2R) showed lower mortality but higher antibody titers than B10.A(4R) mice (Class \& Deelder 1980). Mendlovic et al. (1989a, b) further explored the effects of I-A and I-E on the responses of congenic mice to crude and purified antigens.

Jones et al. (1983) used $\mathrm{H}-2^{\mathrm{b}}$ and $\mathrm{H}-2^{\mathrm{k}}$ mice on both the $\mathrm{C} 57 \mathrm{BL} / 10$ and $\mathrm{BALB} / \mathrm{c}$ backgrounds and found that both the strain background and the $\mathrm{H}-2$ haplotype influenced antibody response and passage of eggs in the feces. The effects of crosses between mouse strains were complex (Jones \& Kussel 1985).

Kee et al. (1986) tested fractionated antigens in mice with a variety of haplotypes and found that a $14 \mathrm{kDa}$ fraction was recognized only by $\mathrm{H}-2^{\mathrm{k}}$ mice while an $86 \mathrm{kDa}$ fraction was not recognized by any of $4 \mathrm{H}-2^{\mathrm{b}}$ strains of mice. Responses to the $86 \mathrm{kDa}$ fraction were further examined by Schweitzer and Taylor (1991) and Schweitzer (1992). Trzyna and Cordingley (1993) found $\mathrm{H}-2^{\mathrm{b}}$ mice unable to produce IgG to a major egg antigen, p-40 and Hernandez et al. (1997c, 1998). Stadecker and Hernandez (1998) and Hernandez and Stadecker (1999) found that H$2^{\mathrm{k}}$ mice, including $\mathrm{C} 3 \mathrm{H}$ and $\mathrm{B} 10 . \mathrm{Br}$, made a T-cell response to a recombinant fraction of $\mathrm{p} 40$ while $\mathrm{C} 57 \mathrm{BL} / 6$ mice $(\mathrm{H}-$ $2^{b}$ ) did not. Granuloma size and other pathologic changes did not, however, follow $\mathrm{H}-2$ haplotypes in a large number of mouse strains examined nor in congenic mice (Fanning et al. 1981, Colley et al. 1983, Fanning \& Kazura 1985, Cheever et al. 1987).

\section{Comparison of Granuloma Formation and Regulation in Infected Animals Versus the Response to Injected Eggs}

The lung model allows study of granuloma formation and cytokine production in vivo in naive animals at defined periods after egg injection and the model allows sensitization with defined antigens or antigenic fractions as well as the testing of defined antigens as targets, i.e. the injection of antigens on beads which are roughly the size of schistosome eggs. Although the lung model generally seems to reflect the sequence of events, and regulation, present during the course of infection induced by cercariae, important exceptions exist. Administration of IL-13R fusion protein, inhibiting IL-13 function, dramatically reduced granuloma size around eggs injected into the lung (Chiramonte et al. 1999a) but did not affect the size of hepatic granulomas in infected mice (Chiramonte 1999b). Additionally, although granulomas around injected eggs were downregulated by the injection of anti-IL-4 granulomas around eggs laid by worms in infected animals, in the lung or in the liver, were not (Cheever et al. 1994c). The differences were attributed to the inferior antigenic quality of eggs extracted from the tissues as neither the site of granuloma formation nor the state of sensitization of the host were important (Eltoum et al. 1995). Granulomas around eggs injected into the lungs downregulate in a fashion similar to hepatic granulomas while granulomas around pulmonary eggs shunted from the portal system in infected mice are not downregulated (Sousa Vidal et al. 1993). In infected IL-10 ko mice, liver granulomas were larger than in control mice while granulomas in the lung of sensitized mice were smaller in IL-10 ko mice than in controls (Wynn et al. 1997, 1998).

Although Eltoum et al. (1995) did not find the site (lung vs liver) of the granulomas to be important, there are obvious differences in the liver and lung, e.g. the hepatic and pulmonary microenvironments are different and the miracidia in eggs injected via the tail vein are killed much more rapidly than those in eggs injected into the portal vein (Feldman et al. 1990) and all remnants of the eggs are 
removed from the lungs more quickly (Cheever \& Anderson 1971, Almeida \& Andrade 1983). Kupffer cells in the liver of infected mice contribute to the type 2 reaction (Hayashi et al. 1999).

ICAM-1 was the only adhesion molecule identified in the liver of infected wild type (control) mice (Ritter \& McKerrow 1996) while VCAM-1 was the predominant adhesion protein identified in the vicinity of lung granulomas (Ritter \& McKerrow person. commun.). VCAM-1 was seen in the livers of infected ICAM-1 ko mice, affording a striking illustration of the ability of ko mice to adapt to their deficiencies (Ritter \& McKerrow 1996). However, VCAM-1 was found to be rapidly upregulated in the livers of infected-wild type mice by Rathore et al. (1996), a result in apparent conflict with the above. Leptak and McKerrow (1997) found little IL-4 in livers of mice given injected portal eggs and postulate that TNF- $\alpha$ plays a prominent role in the formation of hepatic granulomas while IL-4 is important for initiation of pulmonary granulomas, but Eltoum et al. (1995) found similar levels of IL-4 mRNA after injection of eggs at either site.

The regulation of granuloma size in the mouse gut also differs from that in the liver (Weinstock \& Boros 1981, Jacobs et al. 1998a).

\section{HEPATIC FIBROSIS}

\section{General}

Hepatic fibrosis is related to the immune response to the egg and is virtually absent in infected nude and SCID mice (Cheever et al. 1994a, Cheever et al. 1999) or in mice infected with only male or female parasites.

Female $\mathrm{C} 3 \mathrm{H} / \mathrm{HeNN}$ mice infected with 25 male worms for $20 \mathrm{wk}$ had only $2.21 \mu$ moles of hydroxyproline per liver as compared to 1.53 in uninfected mice and 30 in mice infected with 2-3 worm pairs. However mice unisexually infected for $8 \mathrm{wk}$ and then given bisexual infections modulated fibrosis (but not granuloma size) and had $21 \%$ less fibrosis ( $p<0.05$ in each of two experiments) than control mice given the same infection (Cheever et al. unpublished).

The regulation of fibrosis is often independent of the regulation of granuloma size, i.e. larger granulomas are not always associated with greater hepatic fibrosis (Olds et al. 1989, Cheever et al. 1994c, Phillips et al. 1996, Cheever 1997, Chiramonte et al. 1999b, Fallon et al. 2000b). Hepatic fibrosis in schistosome infected mice is clearly linked to IL-13 and the Th2 response, although fibrosis also clearly sometimes occurs around granulomas formed in the Th1 melieu (Chen \& Boros 1999, Hernandez et al. 1999, Hoffmann et al. 2000, Hesse et al. 2000).

Animals treated with anti-IL-4 showed a decrease in Th2 response, an increased Th1 response and a reduction in hepatic fibrosis (Cheever et al. 1994c). IL-13 is even more important for fibrosis and treatment of infected mice with sIL-13R $\alpha 2 \mathrm{Fc}$ fusion protein led to a marked decrease in fibrosis with little effect on granuloma size (Chiramonte et al. 1999b). IL-4 ko mice treated with sIL-13R had tiny granulomas but fibrosis equivalent to that in SIL-13R treated wild type (WT) mice, although the cytokine pattern was Th2-like in WT mice and Th1-like in IL-4 ko mice (Chiramonte et al. 1999b) and in IL-4R ko mice, in which neither IL-4 or IL-13 can signal in the absence of the re- ceptor (Jankovic et al. 1999). Mice treated with anti-IL-4 might be expected to have low IL-13 levels. IL-13 ko mice had granulomas the same volume as wild-type mice but showed minimal fibrosis (Fallon et al. 2000b). Arginase-1 activity is important in influencing both granuloma size and hepatic fibrosis, probably through increasing hepatic proline levels (Hesse et al. 2001).

Mice vaccinated with eggs + IL-12 before infection developed an increased Th1-like cytokine response, a moderate decrease in granuloma size and a marked decrease in hepatic fibrosis (Wynn et al. 1995). This effect is dependent on IFN- $\gamma$, IL-12 and TNF- $\alpha$ (Hoffmann et al. 1999) and mediated through nitric oxide synthase- 2 (Hesse et al. 2000). Treatment with IFN- $\gamma$ resulted in a marked decrease in hepatic fibrosis (Czaja et al. 1989a) but antiIFN- $\gamma$ had no effect on granuloma size or hepatic fibrosis in infected mice (Sher et al. 1990). SEA given without adjuvant intravenously or intraperitoneally before infection also affected granuloma size (Botros et al. 1997) and fibrosis (uncorrected for egg number, Pancré et al. 1999). Hassanein et al. (2001) noted amelioration of pathology in mice immunized intravenously with either SEA or recombinant $S$. mansoni glutathione S-transferase.

Wolowczuk et al. (1997) reported that a single subcutaneous dose of IL-7 given at the site of exposure to $S$. mansoni increased worm recovery and hepatic collagen ( $\mu \mathrm{g}$ collagen $/ \mathrm{mg}$ protein) but their analysis of fibrosis did not allow for the increased intensity of infection in treated mice. IL-7 ko mice had small granulomas and little fibrosis (Woloczuk et al. 1999) and IL-7 Tg mice showed increased fibrosis (Roye et al. 2001). A somatostatin inhibitor, octreotide, diminishes hepatic fibrosis in infected mice (Mansy et al. 1998).

Hepatic fibrosis in infected mice is related to egg numbers, but not in a linear fashion, i.e. mice with heavier infection have more total hepatic fibrosis but less fibrosis per egg (Cheever 1986). The rate of hepatic fibrosis, as indicated by collagen mRNA (Wynn et al. 1995a, b) or collagen synthetic rates (Olds et al. 1989), was decreased in chronically infected mice compared to those with acute (6-8 wk) infections. However Takahashi and Simpser (1981) felt that decreasing levels of collagenase in chronic infections were more important than decreased synthetic rates and in acute infections mice receiving a single injection of concanavalin A showed increased collagenase activity and decreased hepatic collagen (Takahashi \& Koyayashi 1982). We are unaware of attempts to adjust the rate measurements of hepatic fibrosis for infection intensity. Collagen synthetic rates were proportional to liver collagen per egg in ICR mice with high fibrosis compared to C57BL/ 6 mice with low fibrosis (Cheever et al. 1983).

Widely different rates of resorption of hepatic collagen have been reported following chemotherapeutic cure of infection (Morcos et al. 1983, Andrade \& Grimaud 1986, Cheever et al. 1992a), but in general collagen resorption is relatively rapid (collagen half-life of wk or months) in mice treated during the first few weeks of egg deposition and much more gradual when chronically infected mice were treated (Warren \& Klein 1969). The morphologic pattern of collagen resorption in mice resembles that in humans (Andrade \& Grimaud 1988, Andrade et al. 1992). Colchi- 
cine treatment did not decrease hepatic fibrosis in $S$. mansoni-infected mice (Badawy et al. 1999).

\section{Symmers' Clay Pipestem Fibrosis}

Symmers' fibrosis is present in virtually all cases of portal hypertension attributable to schistosome infection in humans and nearly all cases with Symmers' fibrosis at autopsy also manifest signs of portal hypertension. Symmers' fibrosis in the chimpanzee was morphologically indistinguishable from that in man but did not produce portal hypertension (Sadun et al. 1970), probably because of the extensive portal-systemic collaterals formed. Njenga et al. (1998) and Nyindo and Farah (1999) describe, but do not convincingly illustrate, Symmers'-like periportal fibrosis in S. mansoni-infected baboons and Farah et al. (2000) relate portal fibrosis in baboons to reinfection and TGF- $\beta$ and IL-4 production.

The massive infections present in mice produce a portal hypertension related to granuloma number and size which is probably not relevant to the mechanism of portal hypertension in humans (Cheever 1965a). However, mice also share the obstructive portal-venous lesions apparently responsible for portal hypertension in humans. Portal fibrosis resembling Symmers' fibrosis in humans was first described in mice by Warren (1966). Andrade (1987) and Andrade et al. (1997) described similar fibrosis in infected mice in which low intensity infections allowed gradual obstruction of peripheral portal venules with subsequent preferential shunting of eggs into the portal spaces surrounding larger veins. In infected persons it was also noted that eggs did not concentrate in the large portal spaces until pipestem fibrosis had already begun (Cheever 1969). Splenectomized mice developed pipestem fibrosis but less frequently than intact mice (Andrade et al. 1998).

Henderson et al. (1993) not only described a more marked and uniform Symmers'-like fibrosis in infected CBA male mice but also related this fibrosis to the absence of regulatory idiotypic antibodies in these mice, a finding strikingly similar to their findings in humans with Symmers' fibrosis (Montesano et al. 1990a, b). Exposure of neonatal mice to cross-reactive idiotypes (CRI) of mice without portal fibrosis, but not to CRI of mice with portal fibrosis, resulted in decreased granuloma size and decreased hepatic fibrosis in mice subsequently infected (Montesano et al. 1999b). Thus both mechanistic and immunological mechanisms in the murine model of pipestem fibrosis resemble those in humans. These CBA mice also had elevated serum levels of TNF- $\alpha$ and TNF- $\alpha$ mRNA in their livers (Adewusi et al. 1996) and decreased levels of IL-10 (Bosshardt et al. 1997). However idiotypes from mice without portal fibrosis stimulated IFN- $\gamma$ formation (Montesano et al. 1997). Clinical hepatosplenic disease in humans was associated with a Th1-type immunological response (Mwantha et al. 1998) but Montenegro et al. (1999) saw IFN- $\gamma$ production in such patients only after neutralization of IL-10. Mice with and without pipestem hepatic fibrosis did not show differences in the production of anti-idiotypic antibodies against $S$. mansoni (Andrade et al. 1998).

Gross examination of the livers of mice (and other rodent hosts) can be misleading. Macroscopic white thick- ening of the portal areas is frequent in chronic infections, but microscopically this usually reflects marked proliferation of bile ducts rather than fibrosis. Bile duct proliferation is often associated with eosinophilic crystals in the duct lumen. The crystals are apparently derived from epithelial secretions and not eosinophils. Similar changes are seen in the lungs of chronically infected mice and are presumably IL-4 and IL-13 dependent as similar crystals are seen in the lungs of IL- 4 and IL-13 transgenic mice.

\section{Extrahepatic Pathology}

Lung - The key pulmonary pathology in infected humans is granulomatous schistosomal pulmonary arteritis resulting in pulmonary hypertension and cor pulmonale. Granulomatous pulmonary arteritis is seen routinely in mice injected with schistosome eggs, but the attempts to model human pulmonary schistosomiasis have generally involved the shunting of eggs in infected animals to the lungs through partial ligation of the portal vein which created a shunt from the portal system to the lungs (Warren 1964) producing granulomatous pulmonary endarteritis similar to that in infected humans (Andrade \& Andrade 1970), lesions only partially reversed by chemotherapy (Almeida \& Andrade 1983). Granulomas in the lungs of shunted mice did not undergo the downmodulation in size seen in the livers of the same animals after chronic infection (Souza Vidal et al. 1993).

Pulmonary granulomas in mice with portacaval shunts were resistant to downregulation by anti-IL-4 while granulomas around intravenously injected eggs were downregulated, a difference attributed to the lower antigenic potency of the eggs injected compared to those laid in situ by the worms (Eltoum et al. 1995).

Intestines - Granulomas in the colon and small intestine of mice are smaller than those in the liver, are not always subject to the same downregulation (Weinstock \& Boros 1981, Jacobs et al. 1998a) and are associated with less fibrosis than are hepatic granulomas (Dunn \& Kelley 1979, Santos et al. 1992). Inflammatory colonic polyps were seen in S. mansoni-infected chimpanzees (Sadun et al. 1970) but these did not ulcerate and were not associated with diarrhea, a hallmark of schistosomal colonic polyposis in man. Heavily infected animals of several species may develop colonic ulcerations and bloody diarrhea but it is unclear whether these bear any relation to lesions or symptoms and signs in humans. Infected woodchucks have only slight hepatic fibrosis but marked fibrosis of the intestine (Andrade et al. 2001).

Alterations in the vasculature and innervation of the intestines of infected mice have been reported (Kloetzel 1971, Block 1980, Varilek et al. 1991). Death of intestinal neurons is uncommon (Nassauw et al. 2001). In spite of the predominance of small intestinal over colonic pathology in infected mice and the evident gross and microscopic lesions, the functional changes seem slight. Domingo and Warren (1966) did not find functional changes in the guts of infected mice while Vengesa and Lesse (1979) and Sadek et al. (1986) noted changes in the absorption of glucose and fluid transport and of disaccharidase activity. Moreels et al. (2001) found that at 12 but not $8 \mathrm{wk}$ after infection that increased muscular con- 
tractility was present in the inflammed mouse gut and that transit through the GI tract was decreased. Immunodeficient mice may have severe intestinal disease, as noted below under "Causes of Death".

Kidneys - The glomerulonephritis seen in schistosome infected humans has not been described in $S$. mansoni infected animals although both chimpanzees and rabbits seem susceptible to this lesion when infected with S. japonicum. S. mansoni infected rabbits show similar changes, albeit of a lesser degree (Andrade et al. 1988). Mild glomerular lesions in infected capuchin monkeys were described by de Brito et al. (1971) and in baboons by Houba et al. (1977). Houba (1979) reviewed experimental schistosomal glomerulopathy.

Glomerular deposits of immune complexes and ultrastructural glomerular lesions and Ig deposits have been described in infected mice, but the kidneys were often normal by light microscopy (Andrade \& Susin 1974, Rousse \& Romeiro 1974, Natali \& Cioli 1976, Carneiro \& Lopes 1986, Water et al. 1988). Antigen and immune complex deposition were augmented by portocaval shunting (van Marck et al. 1977) but were present even in unisexual infections (Lopes et al. 1981). El-Sherif and Befus (1988) found $\operatorname{IgA}$ to be the predominant Ig isotype in the glomeruli of infected mice. Severe glomerulonephritis developed in female BXSB mice exposed to $10 \mathrm{~S}$. mansoni cercariae but most mice did not have granulomas in the liver and unisexual infections were not ruled out (Fugiwara et al. 1988). Hematuria was documented in a substantial proportion of infected mice by Valadares and Pereira (1983).

S. mansoni-infected hamsters developed severe amyloidosis of the kidneys which resulted in marked ascites and amyloidosis of the liver and spleen, which complicates interpretation of the lesions in these organs (Cheever 1965b).

Central Nervous System - No proper model has been described for the focal mass lesions most frequently reported in humans, but Aloe et al. (1996) have described granulomas in the brain and altered nerve growth factor levels in chronically infected mice. Behavioral changes have been noted in mice and are perhaps attributable to effects of cytokines on the central nervous system (Fiore et al. 1996). Focal egg deposition and granulomatous encephalitis associated with convulsions were seen in an infected cercopithecus monkey (Cheever \& Duvall 1974). Recently, Silva et al. (2002) have called attention to the inadequacy of the murine model for studies concerning neuroschistosomiasis.

\section{Causes of Death}

Causes of death in patients - Humans rarely die from acute $S$. mansoni infections. Nearly all persons with lethal chronic infections have Symmers' fibrosis and most of these die from bleeding esophageal varices. Others with Symmers' fibrosis die with chronic hepatocellular failure and a smaller number from complications of pulmonary hypertension or glomerulonephritis (Cheever \& Andrade 1967) but death from schistosomiasis in patients without Symmers' fibrosis is very uncommon.

Variability between laboratories - It is clear that in some laboratories lethal infections in mice are associated with lower numbers of infecting worms than in other labo- ratories. It is unclear whether this should be attributed to the parasite, the host, to concomitant bacterial or viral infections or to other variables associated with animal husbandry.

Acute hemorrhage into the gastrointestinal tract causes the great majority of deaths in S. mansoni infected mice in our experience. $\mathrm{A} / \mathrm{J}$ mice incur this complication early in infection and at low infection intensities (Dean et al. 1981, Colley \& Freeman 1983) while C57BL/6 and $\mathrm{BALB} / \mathrm{c}$ mice are unusually resistant to death after infection. The mechanism of intestinal hemorrhage in mice is unrelated to gastrointestinal hemorrhage in humans with schistosomiasis. Esophageal varices in the mouse are on the serosal surface of the esophagus and are not the source of bleeding, which is presumably from minute lesions in the gut. This does not seem to be a cause of death in other models, and perhaps is lethal for the mouse because it cannot afford to lose the $1-2 \mathrm{ml}$ of blood involved.

Cytokine shock in mice - Marked malaise and early death without hemorrhage into the gut lumen were reported in IL-4 ko mice on the C57BL/6 background, but not in IL-4 ko mice which were F1 129JxB6. The lethal effect was related to IFN- $\gamma$ and NO (La Flamme et al. 2001, Patton et al. 2002) but was independent of IL-12 (Patton et al. 2001). Survival was improved by treating the mice with anti-TNF- $\alpha$ or with recombinant IL-4 (Rosa Brunet et al. 1997a, b, 1999). Mice deficient in IL-4 and IL-13 are especially susceptible and Fallon et al. (2000b) give an excellent detailed description of the pathogenesis of cytokine shock in these mice, including the shift to a type 1 type cytokine response and the effects of bacterial lipopolysaccharides leaking into the circulation from the intestine. Fallon (2000d) provides an excellent review. Hoffmann et al. (2000) found that either extreme Th1 or Th2 polarization resulted in the early death of $S$. mansoni-infected mice but probably not from cytokine shock in Th2 polarized mice.

Other immunocompromised mice die in the first wk of egg laying without evident cytokine shock. Fallon et al. (2000) found that mice transgenic for IL-9 developed a fatal enteropathy in a Th2 melieu and MacDonald et al. (2002) noted wasting and early death of CD154 ko mice which had impaired Th2 responses.

T cell deficient mice, including SCID and nude mice, infected with $S$. mansoni, but not $S$. japonicum or $S$. haematobium, frequently die 7-9 wk after infection, apparently from hepatotoxicity [and presumably cytokine shock] (Byram et al. 1979, Cheever et al. 1999). Mice deficient in Class II MHC (Angyalosi et al. 1998), CD-4 depleted mice (Fallon et al. 2000a) or made tolerant to $S$. mansoni egg antigens seem to die a similar death (Fallon $\&$ Dunne 1999). Gharib et al. (1999) have described increased eosinophil peroxidase activity and increased oxygen radical production (Abdallahi et al. 1999) in the livers of $S$. mansoni-infected mice with a concomitant decrease in hepatic antioxidant defenses, apparently predisposing infected mice to hepatotoxicity. It is not clear that the entities we have attributed to "cytokine shock" are all similar nor has this toxicity in mice been shown to be relevant to death or other illness in humans (Cheever et 
al. 2000). If the syndrome is related to acute schistosomiasis then it is not clear why immunodeficient mice do not show cytokine shock when infected with schistosome species other than S. mansoni (Cheever et al. 2000).

\section{WORM DEVELOPMENT, FECUNDITY AND FECAL EGG EXCRETION}

Fewer worms develop in male rodent hosts than in females and castration and exogenous hormones have the expected effects (Berg 1957, Nakazawa et al. 1997). Fulford et al. (1998) propose that in mice and in humans that this might be related to dehydroepiandrosterone levels. Worm development and egg production were delayed in mice deficient in the 5th component of complement at 7 wk of infection (Ruppel et al. 1982) but no difference was found in another laboratory at $12 \mathrm{wk}$ (Cheever et al. 1987). Biozzi high responder mice developed higher numbers of parasites and larger worms, and significantly more eggs/ worm pair were found in the liver at 10 but not at $15 \mathrm{wk}$ (Blum \& Cioli 1978). IL-7 deficient mice had fewer worms and fewer eggs/female 7-8 wk after infection (Wolowczuk et al. 1999).

Decreased numbers of eggs/worm pair were found in the livers of severely malnourished mice and hepatic granulomas in these mice were smaller than in well nourished mice (Knauft \& Warren 1969, Akpom \& Warren 1975, Coutinho et al. 1997) and pipestem fibrosis was absent and total hepatic fibrosis diminished in malnourished mice (Coutinho et al. 1997).

Fecundity is defined as the number of eggs laid per day per worm pair. Delayed inception of egg laying is more common than decreased fecundity so that measurement of eggs/worm pair at a single point in acute infections is of limited value. Strictly speaking one should know the total number of eggs in the tissues and eggs passed in the feces to calculate fecundity. Generally, only the number of eggs in the liver and intestines is known, and this comprises almost all eggs in the tissues. Eggs destroyed in the tissues also constitute a portion of the eggs laid and in rhesus monkeys the rate of egg destruction was extremely rapid [half life of 8 days] (Cheever \& Powers 1971) and the same has been assumed to be true for cercopithecus monkeys and baboons (Cheever \& Duvall 1974, Damian et al. 1986). In mice egg destruction is much slower and its effects can often be ignored (Cheever et al. 1992a). Quantitative estimates of worm fecundity for many of these species have been presented previously (Cheever et al. 1994b). Farah et al. (1997) described higher fecundity in multiply infected baboons than after single infection.

In mice infected with a single pair of worms, fecundity varied greatly between individual mice but did not vary with duration of infection (Cheever et al. 1994a). Fecundity did decrease in time in more heavily infected mice (Cheever et al. 1994b). Worm fecundity in vitro also varied greatly among worm pairs and with the host used and the duration of infection (El Ridi et al. 1997). The fecundity of worms in infected rhesus monkeys decreased with increasing duration of infection. This decrease was much more rapid in heavily infected animals than in those lightly infected and the decrease in fecundity presumably had an immune basis as worms were also much more rapidly destroyed in the heavily infected monkeys (Cheever \& Powers 1969).

The fecundity of the worms was generally reflected by the number of eggs passed in the feces at various stages of infection in mice (Cheever et al. 1994b) and in monkeys (Cheever \& Powers 1969). The percentage of eggs laid passed in the feces can vary greatly in different species and even in different strains of mice (Jones et al. 1989). Nude mice (Cheever et al. 1993) and T-cell depleted mice (Dunne et al. 1983, Doenhoff et al. 1978, 1985) passed less eggs in the feces than did intact mice and SCID mice passed almost no eggs in the feces in the first weeks of oviposition (Amiri et al. 1992, Cheever et al. 1999). These findings anticipated those in patients with AIDS who may pass many fewer eggs in the feces than comparably infected patients without AIDS (Karanja et al. 1997). The number of eggs per worm pair in the tissues of nude and SCID mice was low early in infection (Amiri et al. 1992, Cheever et al. 1993, 1999) but the rate of egg accumulation approached that in intact mice by the 10th wk of infection (Cheever et al. 1993, 1999). Davies et al. (2001) correlate worm development with the presence of a subset of $\mathrm{CD} 4^{+}$ lymphocytes in the liver.

Lenzi et al. (1987) found that eosinophils favored the passage of $S$. mansoni eggs in the feces, although mice treated with anti-IL-5 and lacking eosinophils passed normal numbers of eggs in the feces (Sher et al. 1990). Worms in mice deficient in IL-4 or IL-4 and IL-13 showed normal to slightly increased fecundity as judged from tissue eggs but almost no eggs were passed in the feces (Fallon et al. 2000b).

More selective immune depletion, i.e. treatment with anti-IgE, has been reported to inhibit the development of $S$. mansoni suggesting that the worms need this immunoglobulin for normal development (Amiri et al. 1994). This is difficult to reconcile with the increased numbers of worms developing in IgE ko mice (King et al. 1997) and the normal development of worms in FceRI ko mice, in B cell ko mice and in SJA/9 mice unable to produce $\mathrm{IgE}$ (Jankovic et al. 1997, 1998, El Ridi et al. 1998).

\section{INTERACTION OF SCHISTOSOMIASIS WITH OTHER DISEASES}

Murine viral hepatitis was more severe in schistosome infected mice (Warren et al. 1969) and the clearance of vaccinia virus was delayed for a period during the acute phase of schistosome infection (Actor et al. 1994). Woodchuck hepatitis B infection was apparently not affected by $S$. mansoni infection (Andrade et al. 2001). Surprisingly hepatitis B replication in HBV transgenic mice was inhibited by S. mansoni infection (McClary et al. 2000).

Schistosomiasis is intriguingly related to several bacterial infections, most notably with prolonged typhoid fever syndromes (Chieffi 1992) and numerous experimental studies have been published using a number of bacterial species (Rocha et al. 1980). The association of bacteria with the schistosome gut or tegument (Loverde et al. $1980)$ protects the bacteria from chemotherapy and presumably from immune attack as well. 
S. mansoni infected mice also showed increased susceptibility to Entamoeba histolytica (Knight \& Warren 1973), Trypanosoma cruzi (Kloetzel et al. 1973) and Toxoplasma gondii (Kloetzel et al. 1977). Marshall et al. (1999) found increased plasma TNF- $\alpha$ and increased hepatotoxicity in mice with combined $S$. mansoni and T. gondii infections and this effect was diminished in IL-12 ko mice (Araujo et al. 2001). The susceptibility to Plasmodium yoelli and $P$. berghei was little affected (Lwin et al. 1982).

There has long been controversy about the association of human hepatocellular carcinomas and schistosome infections, but $S$. mansoni infection is apparently not associated with hepatoma in man (Cheever \& Andrade 1967). Hepatomas are infrequently seen in infected animals but infected mice given low doses of some carcinogens developed hepatomas much more frequently than did mice given the carcinogen alone (Domingo et al. 1967, Kakizoe 1985).

The vigorous Th2 response to schistosome infection may have a role in several of the above situations and in the response to immunizing antigens such as diphtheria toxoid (Haseeb \& Craig 1997). Diabetes was ameliorated in NOD (non-obese diabetic) mice infected with S. mansoni or injected with eggs (Cooket et al. 1999) and oral administration of SEA plus insulin led to a Th2 response in NOD mice (Maron et al. 1998). Second helminth infections may be influenced as well. Mice usually susceptible to Trichuris muris resolved their infections when infected with S. mansoni (Curry et al. 1995).

\section{USE OF SCHISTOSOME-RELATED MODELS FOR THE STUDY OF OTHER DISEASES}

Many of these studies are implicit in the discussion above. Schistosome infections have been widely used as an example of hypersensitivity granulomas (Boros 1983) and as model systems to examine the biochemistry and morphology of hepatic collagen formation (Silva et al. 1990 Prakash et al. 1995, Frizell et al. 1995) or resorption, as noted above. The interactions of the field of immunology and the study of the immunopathology of schistosome infections have been mutually beneficial. The importance of anti-idiotypic $\mathrm{T}$ cell responses in infectious disease was first noted in schistosome infected individuals (Montesano et al. 1990a, b). The study of T helper subsets has been extremely useful in analyzing infections with schistosomes and with other helminths but investigations of these infections have also contributed substantially to our knowledge of Th1 and Th2 lymphocyte subsets (Jankovic \& Sher 1996, Jankovic et al. 2000, MacDonald et al. 2002) and are relevant to understanding other Th2 dominated reactions such as asthma. Sabin et al. (1996) recently used schistosome eggs to demonstrate the importance of eosinophils as an early source of IL-4.

Coelom-associated lymphomyeloid tissue (CALT or milky spots) is greatly expanded in schistosome infected mice and examination of these animals has contributed to our knowledge of CALT (Lenzi et al. 1996). Many other studies have added to our understanding of eosinophils, macrophages, lymphocytes, non B, non T cells, endothelial cells etc.

\section{SPECIAL CONSIDERATION OF THE RABBIT AND WOOD- CHUCK}

Rabbits are a host of choice for the study of the pathology of schistosomiasis japonica. Large periovular granulomas are formed in the liver during acute infection and typical areas of periportal "pipestem" fibrosis appear. However, rabbits are not good hosts for $S$. mansoni since adult worms are eliminated within a few wk after cercarial exposure (Warren \& Peters 1967, Andrade et al. 1988). Furthermore the eggs do not mature in the tissues and do not appear in the stools. Thus the main factor in the pathogenesis of schistosomiasis, the miracidium, is absent and therefore there is no disseminated liver fibrosis, nor obstructive portal vascular lesions and no portal hypertension or splenomegaly. Lesions in the liver are produced by the worms rather than the eggs. The basic lesion is composed of focal phlebosclerosis, vascular dilatation and polypoid endophlebitis. This curious and characteristic lesion is formed by projections of chronically inflamed subintimal connective tissue which are covered by hyperplastic endothelial cells. At first they do not affect the general liver architecture but in severe chronic infection some degree of portal and sepal fibrosis appear and may become prominent in prolonged infections. In extremely severe cases the combination of fibrosis and vascular proliferation may transform the liver into a huge angiomatous organ. Thus focal portal vascular changes caused directly by living or dying adult worms dominate the pathology of schistosomiasis mansoni in rabbits. Periovular granulomas are not a feature and the fibrotic changes do not resemble human "pipestem" fibrosis.

Woodchucks (Marmota monas and M. marmota) are worth considering as an experimental model for schistosomiasis because they are susceptible to both $S$. mansoni and to a hepatitis virus very similar to human hepatitis virus B (Woodchuck hepatitis virus - WHV). They are highly susceptible hosts with several peculiarities. Acute infection can run a severe and fatal course if the cercarial load is heavy (1,000 cercariae or more). Death in these cases is preceded by diarrhea due to intestinal lesions. The most severely damaged organ is the intestines rather than the liver. Large periovular granulomas are numerous in the submucosa and in the muscular coat, the mucosa being least involved. Granulomas in the liver are smaller than those in the intestines and are scattered. They cause some degree of portal fibrosis which is never disseminated or systematized. The infection runs an auto-cure course (Andrade et al. 2001).

\section{SPECIAL CONSIDERATION OF CALOMYS COLLOSUS}

The first report of $S$. mansoni infection in $C$. callosus was from Coelho et al. (1979). Borda (1972) showed experimentally that it is permissive to $S$. mansoni.

Our histopathological observations in C. callosus, infected by percutaneous exposure to 70 cercariae of $S$. mansoni, and killed at 42, 55, 80, 90 and 160 days after infection (six animals/point), have showed some peculiar aspects. In the liver, the granulomas were of two types: larger, in portal spaces, and smaller ones, in the parenchyma, which were often intravascular. The former were usually constituted by internal (periovular) and peripheral zones, while the intra-parenchymatous granulomas, 
during all the studied period, were predominantly composed of large and mature macrophages, often with abundant schistosomal pigment, less eosinophils and neutrophils, and scarce lymphocytes, as described (Lenzi JA et al. 1995, 1998). There was no significant change in the granuloma morphology, size and extracellular matrix composition during the studied periods, suggesting that they are not modulated.
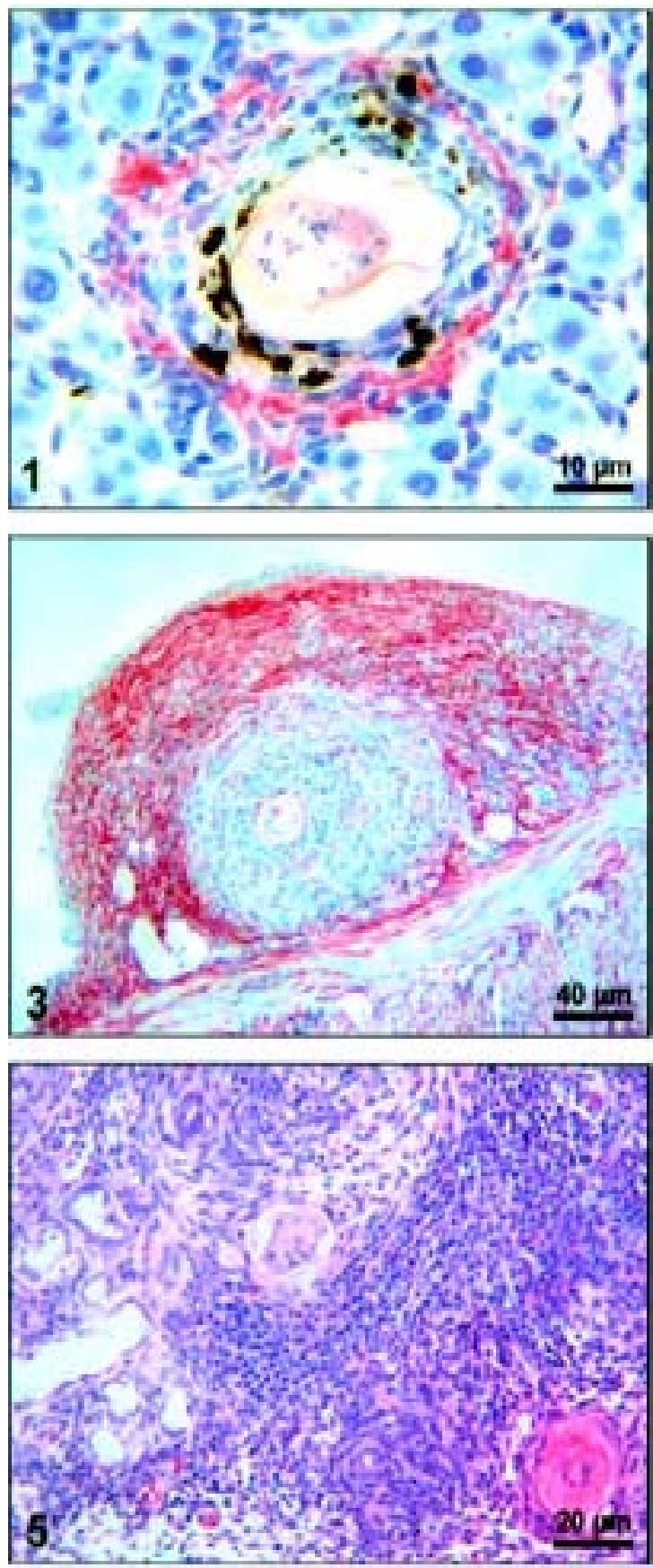

The granulomas exhibited fine texture of reticular fibers, mainly in the periphery and few or absent collagen fibers were visible by picrosirius (Junqueira et al. 1979) or phosphomolybdic acid-picrosirius stains for confocal laser scanning microscopy (Dolber \& Sprach 1993) (Fig. 1). However, they were rich in carboxylated proteoglycans. By immunohistology, they showed deposits of fibronectin, laminin, collagen types I, Pro-III, IV, V, which remained
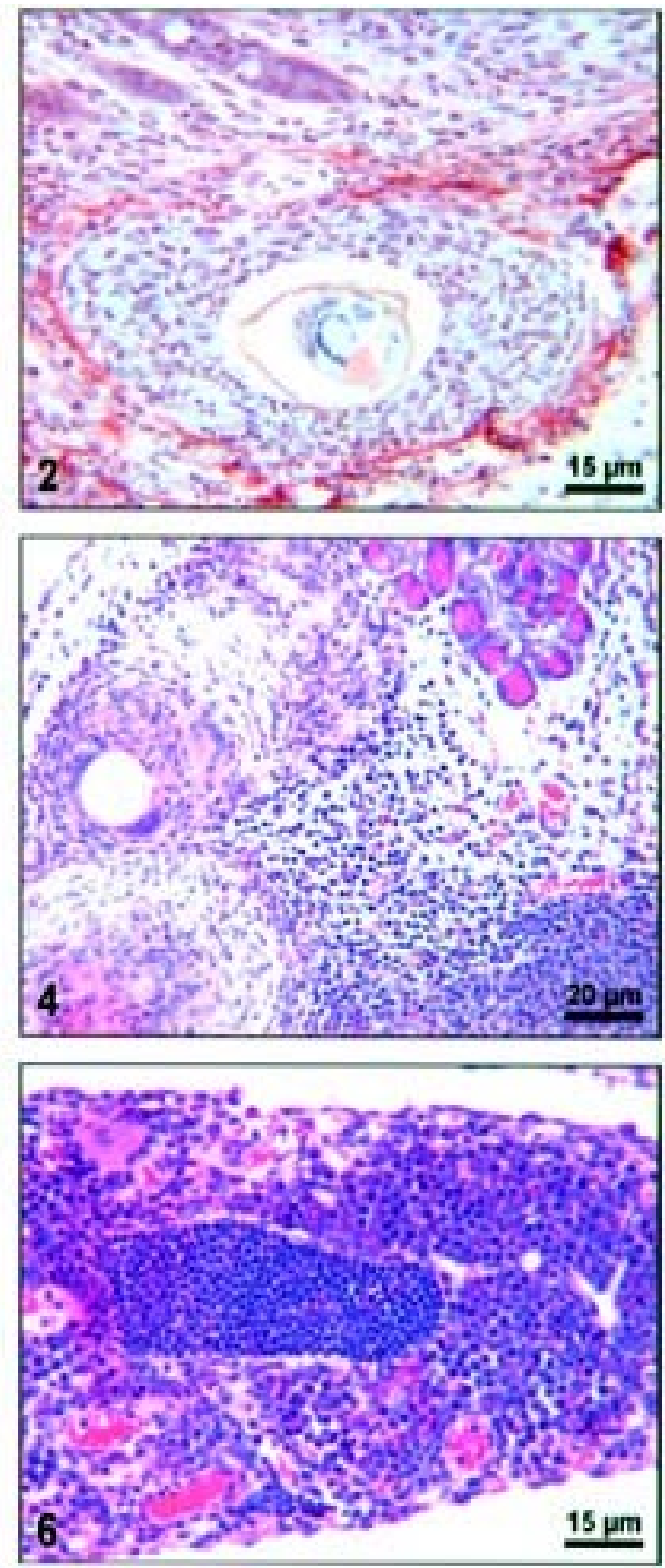

Fig.1: small intraparenchymatous hepatic granuloma with few collagenic fibers, showing large number of macrophages full of schistosome pigment (Picrosirius. Bar $=10 \mu \mathrm{m})$. Fig. 2: granuloma in the intestinal mucosa composed by an internal layer of macrophages and eosinophils surrounded by an external thin collagenic pseudocapsule (Picrosirius. Bar $=15 \mu \mathrm{m}$ ). Fig.3: intestinal subserosal nodule centered by a granuloma, which is encircled by a thick fibrous layer (Picrosirius. Bar $=40 \mu \mathrm{m}$ ). Figs 4 and 5: pancreas with granulomas and focal lobular atrophy, presenting intense interstitial inflammatory infiltrate consisting of lymphocytes, plasma cells and macrophages (H\&E. Bar $=20 \mu \mathrm{m}$ ). Fig. 6: activated Milky Spot rich in plasma cells, showing a lymphatic vessel full of small lymphocytes. Close to the upperleft corner there is a mature megakaryocyte $(\mathrm{H} \& \mathrm{E} . \mathrm{Bar}=15 \mu \mathrm{m})$. 
more or less constant during all the time of infection, always being less than seen in mice. Gelatinase was detected in large macrophages surrounding the eggs.

Focal parenchymal necrosis was found and portal inflammation and fibrosis were varied, depending on the time of infection. They were absent or minimal in more recent infection (42 days). At 90 days in some animals, there was an exacerbation of portal inflammation, and there appeared also portal perivenular and periductal fibrosis, causing sac-like dilatations in portal lymphatics, which filled with large macrophages.

Although the granulomas never exhibited peripheral metaplasia of hematopoietic cells, as observed in mice (Lenzi HL et al. 1995), from 55 days on, intrasinusoidal megakaryocyte, eosinophil and erythroid metaplasia was observed.

In $C$. callosus intestines, there were numerous eggs in all layers forming granulomas with collagen and reticular fibers detected only in the peripheral zone (Fig. 2). Numerous intestinal nodules, appearing from 55 ups to 160 days after infection, were localized at the interface between external muscular layer and intestinal serosa (Fig. 3) (Lenzi JA et al. 2002). From 55 days of infection on, an intense mast cell infiltration was detected, occupying all the intestinal layers. In the mucosa, the mast cells were mainly of the mucosal mast cell-type (MMC), while, in the muscular layer and in the subserosal nodules they were almost exclusively of the connective tissue type (CTMC) or transitional from MMC to CTMC.

Pancreatic involvement was frequent, and occasionally severe (Figs 4,5 ). The omentum and mesentery were strongly activated during the infection, showing many milky spots and a diffuse infiltration of mast cells (Fig. 6). Milky spots were mainly of the lymphoplasmacytic type (Lenzi et al. 1996).

\section{ACKNOWLEDGEMENTS}

To Michelle Frazier-Jessen, Dragana Jankovic, Fred Lewis, Edward Pearce, Laura Rosa-Brunet, W Evan Secor, Sharon Wahl, Thomas Wynn and George Yap for unpublished data and/or for their comments on the manuscript.

\section{REFERENCES}

Abdallahi CMS, Hanna S, DeReggi M, Gharib B 1999. Visualization of oxygen radical production in mouse liver in response to infection with Schistosoma mansoni. Liver 19: 495-500.

Actor JK, Marshall MA, Eltoum IA, Buller RML, Berzofsky JA, Sher A 1994. Increased susceptibility of mice infected with Schistosoma mansoni to recombinant vaccinia virus: association of viral persistence with egg granuloma formation. Eur J Immunol 24: 3050-3056.

Adewusi OI, Nis NA, Lu X, Colley DG, Secor E 1996. Schistosoma mansoni: relationship of tumor necrosis factor- $\alpha$ to morbidity and collagen deposition in chronic experimental infection. Exp Parasitol 84: 115-123.

Akhiani AA, Lycke N, Nilsson LA, Olling S, Ouchterlony O 1996. Lack of interferon- $\gamma$ receptor does not influence the outcome of infection in murine schistosomiasis mansoni. Scand J Immunol 43: 257-262.

Akpom CA, Warren KS 1975. Calorie and protein malnutrition in chronic murine schistosomiasis mansoni: effect on the parasite and the host. J Inf Dis 132: 6-14.
Almeida MAC, Andrade ZA 1983. Effect of chemotherapy on experimental pulmonary schistosomiasis. Am J Trop Med Hyg 32: 1049-1054.

Aloe L, Moroni R, Fiore M, Angelucci F 1996. Chronic parasite infection in mice induces brain granulomas and differentially alters brain nerve growth-factor levels and thermal responses in paws. Acta Neuropathol 92: 300-305.

Amiri P, Haak-Frendscho M, Robbins K, McKerrow JH, Stewart T, Jardieu P 1994. Anti-immunoglobulin E treatment decreases worm burden and egg production in Schistosoma mansoni-infected normal and interferon $\gamma$ knockout mice. $J$ Exp Med 180: 43-51.

Amiri P, Locksley RM, Parslow TG, Sadick M, Rector E, Ritter $\mathrm{D}$, McKerrow JH 1992. Tumor necrosis factor $\alpha$ restores granulomas and induces parasite egg-laying in schistosomeinfected SCID mice. Nature 356: 604-607.

Anderson LA, Cheever AW 1972. Comparison of geographical strains of Schistosoma mansoni in the mouse. Bull WHO 46: 233-242.

Anderson WI, King JM, Uhl EM, Hornbuckle BC, Tenant BC 1991. Pathology of experimental Schistosoma mansoni infection in the eastern woodchuck. Vet Pathol 28: 245-247.

Andrade ZA 1987. Pathogenesis of pipe-stem fibrosis of the liver. (Experimental observation on murine schistosomiasis). Mem Inst Oswaldo Cruz 82: 325-334.

Andrade ZA, Andrade SG 1970. Pathogenesis of schistosomal pulmonary arteritis. Am J Trop Med Hyg 19: 305-310.

Andrade ZA, Grimaud J-A 1986. Evolution of the schistosomal hepatic lesions in mice after curative chemotherapy. Am J Pathol 124: 59-65.

Andrade ZA, Grimaud JA 1988. Morphology of chronic collagen resorption. A study of the late stages of schistosomal granuloma involution. Am J Pathol 132: 389-399.

Andrade ZA, Susin M 1974. Renal changes in mice infected with Schistosoma mansoni. Am J Trop Med Hyg 23: 400-403.

Andrade ZA, Warren KS 1964. Mild prolonged schistosomiasis in mice: alterations in host response with time and the development of portal fibrosis. Trans $R$ Soc Trop Med Hyg 58: 53-57.

Andrade ZA, Berthillon P, Paraná R, Grimaud JÁ, Trepo C 2001. Schistosomiasis mansoni and viral $B$ hepatitis in woodchucks. J Hepatology 34: 134-139.

Andrade ZA, Peixoto E, Gukerret S, Grimaud JA 1992. Hepatic connective tissue changes in hepatosplenic schistosomiasis. Hum Pathol 23: 566-573.

Andrade ZA, Ramos E, Reis MG 1988. A patologia da esquistossomose mansoni no coelho. Mem Inst Oswaldo Cruz 83: 323-332.

Andrade ZA, Silva LM, Souza MM 1997. An experimental approach to the pathogenesis of "pipestem" fibrosis (Symmers' fibrosis of the liver). Mem Inst Oswaldo Cruz. 92: 699-706.

Andrade ZA, Silva LM, Souza MM, Sadigursky M, Barbosa A, Oliveira IR de 1998. Role of the spleen on the pathogenesis of schistosomal periportal (pipestem) fibrosis of the liver: an experimental approach. Am J Trop Med Hyg 59: 557-562.

Angyalosi G, Pancré V, Herno J, Auriault C 1998. Immunological response of major histocompatability complex class IIdeficient $\left(\mathrm{A} \beta^{\circ}\right)$ mice infected by the parasite Schistosoma mansoni. Scand J Immunol 48: 159-169.

Araujo MI, Bliss SK, Suzuki Y, Alcaraz A, Denkers EY, Pearce EJ 2001. Interleukin-12 promotes pathologic liver changes and death in mice coinfected with Schistosoma mansoni and Toxoplasma gondii. Infect Immun 69: 1454-1462.

Assherson GL, Dieli F, Sireci G, Salerno A 1996. Role of IL-4 in delayed type hypersensitivity. Clin Exp Immunol 103: 1-4. 
Badawy AA, El-Badrawy NM, Hassan MM, Ebeid FA 1999. Colchicine therapy for hepatic murine schistosomal fibrosis: image analysis and serological study. Int J Exp Path 80: 25-34.

Barral-Netto M, Cheever AW, Lawley TJ, Ottesen EA 1983. Cell-mediated and humoral immune responses in capuchin monkeys infected with Schistosoma japonicum or $S$. mansoni. Am J Trop Med Hyg 32: 1335-1343.

Berg E 1957. Effects of castration and testosterone in male mice on Schistosoma mansoni. Trans R Soc Trop Med Hyg 51:353-358.

Bergquist NR, Colley DG 1998. Schistosomiasis vaccines: research to development. Parasitol Today 14: 99-104.

Block EH 1980. In vivo microscopy of schistosomiasis. II. The migration of Schistosoma mansoni in the lung, liver and intestine. Am J Trop Med Hyg 29: 62-70.

Blum K, Cioli D 1978. Behavior of Biozzi high and low responder mice upon infection with Schistosoma mansoni. Eur J Immunol 8: 52-56.

Blum AM, Metwali A, Cook G, Mathew RC, Elliott D, Weinstock JV 1993. Substance P modulates antigen-induced, IFN- $\gamma$ production in murine schistosomiasis mansoni. $J$ Immunol 151: 225-233.

Blum AM, Metwali A, Elliott D, Li J, Sandor M, Lynch R, Weinstock JV 1997. IL-6 deficient C57BL/6 mice form granulomas in murine schistosomiasis that exhibit an abnormal B-cell response. J Allergy Clin Immunol 99: 74-74.

Blum AM, Metwali A, Elliott D, Li J, Sandor M, Weinstock JV 1998. IL-6-deficient mice form granulomas in murine schistosomiasis that exhibit an altered B cell response. Cellular Immunol 188: 64-72.

Blum AM, Metwali A, Kim-Miller M, Li J, Qadir K, Elliott DE, Lu B, Fabry Z, Gerard N, Weinstock JV 1999. Substance $\mathrm{P}$ receptor is necessary for a normal granulomatous response in murine schistosomiasis mansoni. $J$ Immunol 162: 6080-6085.

Blum AM, Metwali A, Mathew RC, Cook G, Elliot D, Weinstock JV 1992. Granuloma T lymphocytes in murine schistosomiasis mansoni have somatostatin receptors and respond to somatostatin with decreased IFN- $\gamma$ secretion. $J$ Immunol 149: 3621-3626.

Borda CE 1972. Infecção Natural e Experimental de Alguns Roedores pelo Schistosoma mansoni Sambon, 1907, MSc Thesis, ICB-UFMG, Belo Horizonte, 43 pp.

Borojevic R 1992. Experimental murine schistosomiasis mansoni: establishment of the chronic phase of the disease. Mem Inst Oswaldo Cruz 87 (Suppl. V): 171-174.

Boros DL 1983. Granulomatous inflammations. Prog Allergy 24: 183-267.

Boros DL, Whitfield JR 1998. Endogenous IL-10 regulates IFN$\gamma$ and IL-5 cytokine production and the granulomatous response in schistosomiasis manoni-infected mice. Immunology 94: 481-487.

Boros DL, Whitfield JR 1999. Enhanced Th1 and dampened Th2 responses synergize to inhibit acute granulomatous and fibrotic responses in murine schistosomiasis mansoni. Infect Immun 67: 1187-1193.

Boros DL, Lande MA, Carrick Jr L 1983. The Influence of host and parasite factors on Schistosoma mansoni egg-induced tissue fibrosis. Contr Microbiol Immunol 7: 230-236.

Botros SS, Doughty BL, Shaker ZA, Akl MM, Sharmy R, Diab TM, Hassanein HI 1997. Efficacy of an antipathology vaccine in murine schistosomiasis adminstered with and without chemotherapy. Int J Immunopharmac 18: 707-718.

Bremond P, Pasteur N, Combes C, Renaud F, Theron A 1993. Experimental host-induced selection in Schistosoma mansoni strains from Guadeloupe and comparison with natural observations. Heredity 70: 33-37.

Brito JM, Borojevic R 1997. Liver granulomas in schistosomiasis - mast cell-dependent induction of SCF expression in hepatic stellate cells is mediated by TNF-alpha. J Leukocyte Biol 62: 389-396.

Brown DR, Fowell DJ, Corry DB, Wynn TA, Moskowitz NH, Cheever AW, Locksley RM, Reiner SL 1996. $\beta$-2microglobulin-dependent NK $1.1^{+} \mathrm{T}$ cells are not essential for T helper cell 2 immune responses. J Exp Med 184: 1295 1304.

Byram JE, Doenhoff MJ, Musallam R, Brink LH, von Lichtenberg F 1979. Schistosoma mansoni infections in Tcell deprived mice, and the ameliorating effect of administering homologous chronic infection serum. II. Pathology. Am J Trop Med Hyg 28: 274-285.

Carneiro CRW, Lopes JD 1986. Surface antigen detected by a Schistosoma mansoni monoclonal antibody in worm extracts and kidney deposits of infected mice and hamsters. Infect Immun 52: 230-235.

Catapani WR, Parise ER, Mor MMBL, Sadigursky M, Andrade ZA, Sant'anna OA, Misputen SJ, Siqueira M 1994. Parasite and egg burden, hepatic collagen and histologic pattern of liver granulomas in selection III high and low antibody responder mice infected with Schistosoma mansoni. Mem Inst Oswaldo Cruz 89: 63-67.

Cêtre C, Pierrot C, Cocude C, Lafitte S, Capron A, Capron M, Khalife J 1999. Profiles of Th1 and Th2 cytokines after primary and secondary infection by Schistosoma mansoni in the semipermissive rat host. Infect Immun 67: 2713-2719.

Cheever AW 1965a. A comparative study of Schistosoma mansoni infections in mice, gerbils, multimammate rats and hamsters. I. The relation of portal hypertension to size of hepatic granulomas. Am J Trop Med Hyg 14: 211-226.

Cheever AW 1965b. A comparative study of Schistosoma mansoni infections in mice, gerbils, multimammate rats and hamsters. II. Qualitative pathological differences. Am J Trop Med Hyg 14: 227-238.

Cheever AW 1986. The intensity of experimental schistosome infections modulates hepatic pathology. Am J Trop Med Hyg 35: 124-133.

Cheever AW 1969. Quantitative comparison of the intensity of Schistosoma mansoni infection in man and experimental animals. Trans $R$ Soc Trop Med Hyg 63: 781-795.

Cheever AW 1997. Differential regulation of granuloma size and hepatic fibrosis in schistosome infections. Mem Inst Oswaldo Cruz 92: 689-692.

Cheever AW, Anderson LA 1971. Rate of destruction of Schistosoma mansoni eggs in the tissues of mice. Am J Trop Med Hyg 20: 62-68.

Cheever AW, Andrade ZA 1967. Pathological lesions associated with Schistosoma mansoni infection in man. Tran $R$ Soc Trop Med Hyg 61: 626-639.

Cheever AW, Duvall RH 1974. Single and repeated infections of grivet monkeys with Schistosoma mansoni: parasitological and pathological observations over a 31-month period. Am J Trop Med Hyg 23: 884-894.

Cheever AW, Powers KG 1969. Schistosoma mansoni infection in rhesus monkeys: changes in egg production and egg distribution in prolonged infections in intact and splenectomized monkeys. Ann Trop Med Parasitol 63: 83-93.

Cheever AW, Powers KG 1971. Rate of destruction of Schistosoma mansoni eggs and adult worms in the tissues of rhesus monkeys. Am J Trop Med Hyg 20: 69-76.

Cheever AW, Yap GS 1997. Immunologic basis of disease and disease regulation in schistosomiasis. Chem Immunol 66: 159-176.

Cheever AW, Byram JE, Hieny S, von Lichtenberg F, Lunde 
ML, Sher A 1985. Immunopathology of Schistosoma japonicum and $S$. mansoni infections in B cell depleted mice. Parasite Immunol 7: 399-413.

Cheever AW, Dunn MA, Dean DA, Duvall RH 1983. Differences in hepatic fibrosis in ICR, C3H and C57BL/6 mice infected with Schistosoma mansoni. Am J Trop Med Hyg 32: 1364-1369.

Cheever AW, Duvall RH, Hallack TA Jr, Minker RG, Malley JD, Malley KG 1987. Variation of hepatic fibrosis and granuloma size among mouse strains infected with Schistosoma mansoni. Am J Trop Med Hyg 37: 85-97.

Cheever AW, Eltoum IA, Andrade ZA, Cox TM 1993. Biology and pathology of Schistosoma mansoni and S. japonicum infection in several strains of nude mice. Am J Trop Med Hyg 48: 496-503.

Cheever AW, Hoffmann KF, Wynn TA 2000. Immunopathology of schistosomiasis mansoni in mice and men. Immunol Today [letter] 21: 465-466.

Cheever AW, Jankovic D, Yap GS, Kullberg MC, Sher A, Wynn TA 1998. Role of cytokines in the formation and downregulation of hepatic circumoval granulomas and hepatic fibrosis in Schistosoma mansoni-infected mice. Mem Inst Oswaldo Cruz 93 (Suppl. I): 25-32.

Cheever AW, Lewis FA, Wynn TA 1997. Schistosoma mansoni: unisexual infections sensitize mice for granuloma formation around eggs. Parasitol Res 83: 57-59.

Cheever AW, Macedonia JG, Deb S, Cheever EA, Mosimann JR 1992a. Persistence of eggs and hepatic fibrosis after treatment of Schistosoma mansoni-infected mice. Am J Trop Med Hyg 46: 752-758.

Cheever AW, Macedonia JG, Mosimann JE, Cheever EA 1994a. Kinetics of egg production and egg excretion by Schistosoma mansoni and Schistosoma japonicum in mice infected with a single pair of worms. Am J Trop Med Hyg 50: 269280.

Cheever AW, Mosimann JE, Deb S, Cheever EA, Duvall RH 1994b. Natural history of Schistosoma mansoni infection in mice: egg production, egg passage in the feces and contribution of host and parasite death to changes in worm numbers. Am J Trop Med Hyg 50: 281-295.

Cheever AW, Poindexter RW, Wynn TA 1999. Egg laying is delayed but worm fecundity is normal in SCID mice infected with Schistosoma japonicum and S. mansoni with or without recombinant tumor necrosis alpha treatment. Infect Immun 67: 2201-2208.

Cheever AW, Xu Y, Macedonia JG, Cox T, Caspar P, Hieny S, Sher A 1992c. The role of cytokines in the pathogenesis of hepatic granulomatous disease in Schistosoma mansoni infected mice. Mem Inst Oswaldo Cruz 87 (Suppl. IV): 8185.

Cheever AW, Williams ME, Wynn TA, Finkelman FD, Seder RA, Cox TM, Hieny S, Caspar P, Sher A 1994c. Antiinterleukin-4 treatment of Schistosoma mansoni-infected mice inhibits development of $\mathrm{T}$ cells and non- $\mathrm{B}$, non- $\mathrm{T}$ cells expressing Th2 cytokines while decreasing egg-induced hepatic fibrosis. J Immunol 153: 753-759.

Chen Y, Boros DL 1998. Identification of the immunodominant $\mathrm{T}$ cell epitope of $\mathrm{p} 38$, a major egg antigen, and characteriztion of the epitope-specific Th responsiveness during murine schistosomiasis mansoni. J Immunol 160: 5420-5427.

Chen Y, Boros DL 1999. Polarization of the immune response to single immunodominant epitope of p38, a major Schistosoma mansoni egg antigen, generates Th1- or Th2-type cytokines and granulomas. Infect Immun 67: 4570-4577.

Chen YG, Boros DL 2001. The Schistosoma mansoni egg-derived $\mathrm{r} 38$ peptide-induced Th1 response affects the synchronous pulmonary but not ehe asynchronous hepatic granuloma growth. Parasite Immunol 23: 43-50.

Chensue SW, Boros DL 1979. Modulation of granulomatous hypersensitivity. I. Characterization of T lymphocytes involved in the adoptive suppression of granuloma formation in Schistosoma mansoni-infected mice. J Immunol 123: 1409-1414.

Chensue SW, Remick DG, Higashi GI, Boros DI, Kunkel SL 1986. Modulation of murine schistosomiasis by exogenously administered prostaglandins. Am J Pathol 125: 28-34.

Chensue SW, Terebuh PD, Warmington KS, Hershey SD, Evanoff HL, Kunkel SL, Higashi GI 1992. Role of Il-4 and IFN- $\gamma$ in Schistosoma mansoni egg-induced granuloma formation. Orchestration, relative contribution, and relationship to macrophage function. J Immunol 148: 900-906

Chensue SW, Warmington KS, Alllenspach EJ, Lu B, Gerard C, Kunkel SL, Lukacs NW 1999. differential expression and cross-regulatory function of RANTES during mycobacterial (Type 1) and schistosomal (Type 2) antigen-elicited granulomatous inflammation. J Immunol 163: 165-173.

Chensue SW, Warmington KS, Lukacs NW, Lincoln PM, Burdick MD, Strieter RM, Kunkel S 1995a. Monocyte chemotactic protein expression during schistosome egg granuloma formation. Am J Pathol 146: 130-138.

Chensue SW, Warmington KS, Ruth J, Lincoln PM, Kunkel SL 1994a. Cross-regulatory role of interferon-gamma (IFN- $\gamma$ ), IL-4 and IL-10 in schistosome egg granuloma formation: in vivo regulation of Th activity and inflammation. Clin Exp immunol 98: 395-400.

Chensue SW, Warmington KS, Ruth J, Lincoln P, Kuo M-C, Kunkel SL 1994b. Cytokine responses during mycobacterial and schistosomal antigen-induced pulmonary granuloma formation. Am J Pathol 145: 1105-1113.

Chensue SW, Warmington KS, Ruth JR, Lincoln P, Kunkel SL 1995b. Cytokine function during mycobacterial and schistosomal antigen-induced pulmonary granuloma formation. J Immunol 154: 5969-5976.

Chensue SW, Warmington KS, Ruth JH, Sanghi P, Lincoln P, Kunkel SL 1996. Role of monocyte chemoattractant protein-1 (MCP-1) in Th1 (mycobacterial) and Th2 (schistosomal) antigen-induced granuloma formation. J Immunol 157: 4602-4608.

Chesney J, Metz C, Stavitsky AB, Bacher M, Bucala R 1998. Regulated production of type I collagen and inflammatory cytokines by peripheral blood fibrocytes. J Immunol 160: 419-425.

Chieffi PP 1992. Interrelationship between schistosomiasis and concomitant diseases. Mem Inst Oswaldo Cruz 87 (Suppl. IV): 291-296

Chikunguwo SM, Kanazawa T, Dayal Y, Stadecker MJ 1991. The cell-mediated response to schistosomal antigens at the clonal level: in vivo function of cloned murine egg antigenspecific $\mathrm{CD}^{+} \mathrm{T}$ helper type 1 lymphocytes. J Immunol 147: 3921-3925.

Chiramonte MG, Donaldson DD, Cheever AW, Wynn TA 1999b. An IL-13 inhibitor blocks the development of hepatic fibrosis during a t-helper type- 2 dominated inflammatory response. J Clin Invest 104: 777-785.

Chiramonte MG, Schopf LR, Neben TY, Cheever AW, Donaldson DD, Wynn TA 1999a. IL-13 is a key regulatory cytokine for Th2 cell-mediated pulmonary granuloma formation and $\operatorname{IgE}$ responses induced by Schistosoma mansoni eggs. J Immunol 162: 920-930.

Claas FHJ, Deelder AM 1979. H-2 linked immune response to murine experimental Schistosoma mansoni infection. J Immunogenetics 6: 167-175.

Class FHJ, Deelder AM 1980. Influence of the I-region of the $\mathrm{H}-2$ complex on the immune response to murine Schisto- 
soma mansoni infections. Acta Leidensia 48: 23-27.

Coelho PMZ, Dias M, Mayrink W, Magalhães P, Mello MN, Costa CA 1979. Wild reservoirs of Schistosoma mansoni, from Caratinga, an endemic schistosomiasis area of Minas Gerais State, Brazil. Am J Trop Med Hyg 28: 163-164.

Colley DG, Freeman Jr GI 1983. Difference in adult Schistosoma mansoni worm burden requirements for the establishment of resistance to reinfection in inbred mice. II. C57BL/KsJ, SWR/J, SJL/J, BALB/cAnN, DBA/2N, AJ, B10.A(eR) and B10.A(5R) mice. Am J Trop Med Hyg 32: 543-549.

Colley DG, Lewis FA, Todd CW 1979. Adoptive suppression of granuloma formation by $\mathrm{T}$ lymphocytes and by lymphoid cells sensitive to cyclophosphamide. Cell Immunol 46: 192-200.

Cooke A, Tonks P, Jones FM, O'shea H, Hutchings P, Fulford AJC, Dunne DW 1999. Infection with Schistosoma mansoni prevents insulin dependent diabetes mellitus in non-obese diabetic mice. Parasite Immunol 21: 169-176.

Costa MFFL, Katz N 1982. Comparative study of Schistosoma mansoni strains isolated from patients with toxemic or intestinal forms of schistosomiasis. Am J Trop Med Hyg 31: 499-504.

Costa MFFL, Roche RS, Katz N 1984. Comparative study of Schistosoma mansoni isolated from patients with hepatosplenic and intestinal clinical forms of schistosomiasis. Am J Trop Med Hyg 33: 918-923.

Coulson PS 1997. The radiation-attenuated vaccine against schistosomes in animal models: paradigm for a human vaccine? Adv Parasitol 39: 272-336.

Coutinho EM, de Souza MM, Silva LM, Cavalcanti CL, de Araujo RE, Barbosa Jr. AA, Cheever AW, Andrade ZA 1997. Pathogenesis of schistosmal 'pipestem' fibrosis: a low-protein diet inhibits the development of 'pipestem' fibrosis in mice. Int J Exp Pathol 78: 337-342.

Cuison A, Tasaka K, Chuang C-K, Minai M, Yoshikawa H, Nakajima Y 1995. Schistosome eggs in the portal vein can induce tolerance. Int J Parasitol 25: 993-998.

Curry AJ, Else KJ, Jones F, Bancroft A, Grencis RK, Dunne DW 1995. Evidence that cytokine-mediated immune interactions inducted by Schistosoma mansoni alter disease outcome in mice concurrently infected with Trichuris muris. $J$ Exp Med 181: 769-774.

Czaja MJ, Weiner FR, Flanders KC, Giambrone M-A, Wind R, Biempica L, Zern MA 1989b. In vitro and in vivo association of transforming growth factor- $\beta 1$ with hepatic fibrosis. J Cell Biol 108: 2477-2482.

Czaja MJ, Weiner FR, Takahashi S, Giambrone M-A, van der Meide PH, Schellekens H, Biempka L, Zern MA 1989a. $\gamma$ interferon treatment inhibits collagen deposition in murine schistosomiasis. Hepatology 10: 795-800.

Damian RT, Chapman RW 1983. The fecundity of Schistosoma mansoni in baboons, with evidence for a sex ratio effect. $J$ Parasitol 69: 987-989.

Damian RT, Rawlings CA, Bosshardt SC 1986. The fecundity of Schistosoma mansoni in chronic nonhuman primate infections and after transplantation into naive hosts. $J$ Parasitol 72: 741-747.

Damian RT, Rosa MA de la, Murfin DJ, Rawlings CA, Weina PJ, Xue YP 1992. Further development of the baboon as a model for acute schistosomiasis. Mem Inst Oswaldo Cruz 87 (Suppl. IV): 261-269.

Damian RT, Rosa M de la, Bucci JG, Mohamed FM, Kanamura HY, Chou T-M, Stich RW, Rawlings CA, Weina PJ 1996. Hypothesis derived from the baboon model for the etiology of the symptoms of acute schistosomiasis. Am Soc Parasitologists (Abst 106).
Davies SJ, Grogan JL, Blank RB, Lim KC, Locksley RM, McKerrow JH 2001. Modulation of blood fluke development in the liver by hepatic $\mathrm{CD} 4^{+}$lymphocytes. Science 294: 1358-1361.

Dean DA, Bukowski MA, Cheever AW 1981. Relationshiop between acquired resistance, portal hypertension, and lung granulomas in ten strains of mice infected with Schistosoma mansoni. Am J Trop Med Hyg 30: 806-814.

Debrito T, Gunji J, Camargo ME, Ceravolo A, DA Silva LC 1971. Glomerular lesions in experimental infections of Schistosoma mansoni in Cebus apella monkeys. Bull WHO 45: 419-422.

Denoya VA, Pointer JP, Colmenares C, Theron A, Balzan C, Cesari IM, Gonzalez S, Noya O 1997. Natural Schistosoma mansoni infection in wild rats from Guadeloupe parasitological and immunological aspects. Acta Trop 68: 11-21.

Doenhoff M, Musallam R, Bain J, McGregor A 1978. Studies on the host-parasite relationship in Schistosoma mansoni infected mice: the immunological dependence of parasite egg excretion. Immunology 35: 771-778.

Doenhoff MJ, Hassounah OA, Lucas SB 1985. Does the immunopathology induced by schistosome eggs potentiate parasite survival? Immunol Today 6: 203-206.

Dolber PC, Spach MS 1993. Conventional and confocal fluorescence microscopy of collagen fibers in the heart. $J$ Histochem Cytochem 41: 465-469.

Domingo EO, Warren KS, Stenger RJ 1967. Increased incidence of hepatoma in mice with chronic schistosomiasis mansoni treated with a carcinogen. Am J Pathol 51: 307-321.

Dunn MA, Kelley EP 1979. Organ specificity of fibrosis in murine schistosomiasis. Clin Res 27: 265A.

Dunne DW, Hassounah O, Musallam R, Lucas S, Pepys MB, Baktz M, Doenhoff M 1983. Mechanisms of Schistosoma mansoni egg excretion: parasitological observations in immunosuppressed mice reconstituted with immune serum. Parasite Immunol 5: 1-12.

Edungbola LD, Schiller EL 1979. Histopathology of hepatic and pulmonary granulomata experimentally induced with eggs of Schistosoma mansoni. J Parasitol 65: 253-261.

Eloi-Santos SM, Novatoi-Silva E, Maselli VM, Gazzinelli G, Colley DG, Correa-Oliveira R 1989. Idiotypic sensitization in utero of children born to mothers with schistosomiasis or Chagas' disease. J Clin Invest 84: 1028-1031.

El Ridi R, Ozaki T, Kamiya H 1998. Schistosoma mansoni infection in IgE-producing and IgE-deficient mice. J Parasitol 84: 171-174.

El Ridi R, Ozaki T, Inaba T, Ito M, Kamiya H 1997. Schistosoma mansoni oviposition in vitro reflects worm fecundity in vivo: individual-, parasite age- and host-dependent variations. Int J Parasitol 27: 381-387.

El-Sherif AK, Befus D 1988. Predominance of IgA deposits in glomeruli of Schistosoma mansoni infected mice. Clin Exp Immunol 71: 39-44.

Eltoum IA, Wynn TA, Poindexter RW, Finkelman FD, Lewis FA, Sher A, Cheever AW 1995. Suppressive effect of IL-4 neutralization differs for granulomas around Schistosoma mansoni eggs injected into mice compared to eggs laid in infected mice. Infect Immunity 69: 2532-2536.

Epstein MM, DiRosa F, Jankovic D, Sher A, Matzinger P 1995. Successful T cell priming in B cell-deficient mice. $J$ Exp Med 182: 915-922.

Erickson DG, vonLichtenberg F, Sadun EH, Lucia HL, Hickman RL 1971. Comparison of Schistosoma haematobium, S. mansoni and S. japonicum in the owl monkey, Aotus trivirgatus. J Parasitol 57: 543-558.

Fallon PF 2000. Immunopathology of schistosomiasis: a cau- 
tionary tale of mice and men. Immunol Today 21: 29-35.

Fallon PG, Dunne DW 1999. Tolerization of mice to Schistosoma mansoni egg antigens causes elevated Type 1 and diminished type 2 cytokine responses and increased mortality in acute infection. J Immunol 162: 4122-4132.

Fallon PG, Richardson EJ, Smith P, Dunne DW 2000a. Elevated type-1, dimished type 2 cytokines and impaired antibody response are associated with hepatotoxicity and mortalities during Schistosoma mansoni infection of CD-4depleted mice. Eur J Immunol 30: 470-480.

Fallon PG, Richardson EJ, McKenzie GJ, McKenzie ANJ $2000 \mathrm{~b}$. Schistosome infection of transgenic mice defines distinct and contrasting pathogenic roles for IL-4 and IL13: IL-13 is a profibrotic agent. J Immunol 164: 2585-2591.

Fallon PF, Smith P, Richardson EJ, Jone FJ, Faulkner HC, Van Snick J, Renauld J-C, Dunne DW 2000c. Experssion of interleukin-9 leads to Th2 cytokine-dominated responses and fatal enteropaty in mice with chronic Schistosoma mansoni infections. Infect Immun 68: 6005-6011.

Fanning MM, Kazura JW 1985. Further studie on genetic variation of hepatosplenic disease and modulation in murine schistosomiasis mansoni. Parasite Immunol 7: 213-222.

Fanning MM, Peters PA, Davis RS, Kazura JW, Mahmoud AAF 1981. Immunopathology of murine infection with Schistosoma mansoni: Relationship of genetic background to hepatosplenic disease and modulation. J Inf Dis 144: 148-153.

Farah IO, Mola PW, Kariuki TM, Nyindo M, Blanton RE, King CL 2000. Repeated exposure induces periportal fibrosis in Schistosoma mansoni-infected baboons: role of TGF$\beta$ and IL-4. J Immunol 164: 5337-5343.

Farah IO, Nyindo M, Suleman MA, Hyaudi J, Kariuki TM, Blanton RE, Elson LH, King CL 1997. Schistosoma mansoni: development and modulation of the granuloma after single or multiple exposures in the baboon (Papio cynocephalus anubis). Exp Parasitol 86: 93-101.

Feldman GM, Dannenberg AM Jr., Seed JL 1990. Physiologic oxygen tensions limit oxidant-mediated killing of schistosome eggs by inflammatory cells and isolated granulomas. $J$ Leukocyte Biol 47: 344-354.

Ferru I, Roye O, Delacre M, Auriault C, Wolowczuk I 1998. Infection of B-cell-deficient mice by the parasite Schistosoma mansoni: demonstration of the participation of $\mathrm{B}$ cells in granuloma modulation. Scand J Immunol 48: 233240.

Fiore M, Moroni R, Alleva E, Aloe L 1966. Schistosoma mansoni: influence of infection on mouse behavior. Exp Parasitol 83: 46-54.

Flores Villanueva PO, Harris TS, Ricklan DE, Stadecker MJ 1994. Macrophages from schistosomal egg granulomas induce unresponsiveness to specific cloned Th-1 lymphocytes in vitro and down-regulate schistosomal granulomatous disease in vivo. J Immunol 152: 1847-1855.

Flores-Villanueva PO, Zheng XX, Strom TB, Stadecker MJ 1996. Recombinant IL-10 and IL-10/Fc treatment downregulate egg antigen-specific delayed hypersensitivity reactions and egg granuloma formation in schistosomiasis. $J$ Immunol 156: 3315-3320.

Frizell E, Liu S-L, Abraham A, Ozaki I, Eghball M, Sage EH, Zern MA 1995. Expression of SPARC in normal and fibrotic livers. Hepatology 21: 847-854.

Fugiwara M, Makino M, Watanabe H 1988. Schistosoma mansoni: induction of severe glomerulonephritis in female BXSB mice following chronic infection. Exp Parasitol 65: 214-221.

Fulford AJC, Webster M, Ouma JH, Kimani G, Dunne DW 1998. Puberty and age-related changes in susceptibility to schistosome infection. Parasitol Today 14: 23-26.

Gao J-L, Wynn TA, Chang Y, Lee EJ, Broxmeyer HE, Cooper S, Tiffany HL, Westphal H, Kwon-Chung J, Murphy PM 1997. Impaired host defense, hematopoiesis, granulomatous inflammation and type 1-type 2 cytokine balance in mice lacking CC chemokine receptor 1. J Exp Med 185: 1959-1968.

Gaubert S, da Costa AV, Maurage C-A, Santos Lima EC, Fontaine J, Safitte S, Minoprio P, Capron A, Grzych J-M 1999. X-linked immunodefieiency affects the outcome of Schistosoma mansoni infection in the murine model. Parasite Immunol 21: 89-101.

Gharib B, Abdallahi OMS, Dessien H, Reggi MDe 1999. Development of eosinophil peroxidase activity and concomitant alteration of the antioxidant defenses in the liver of mice infected with Schistosoma mansoni. J Hepatol 30: 594-602.

Goes AM, Gazzinelli G, Rocha R, Katz N, Doughty BL 1991. Granulomatous hypersensitivity to Schistosoma mansoni egg antigens in human schistosomiasis. III. In vitro granuloma modulation induced by immune complexes. Am J Trop Med Hyg 4: 434-443.

Goes AM, Rezende SA, Gazzinelli G, Doughty BL 1994. Granulomatous hypersensitivity to Schistosoma mansoni egg antigens in human schistosomiasis. A role for prostaglandin-induced inhibition of in vitro granuloma formation. Parasite Immunol 16: 11-18.

Green WF, Colley DG 1981. Modulation of Schistosoma mansoni egg-induced granuloma formation: I-J restriction of T cell mediated suppression in a chronic parasitic infection. Proc Natl Acad Sci USA 78: 1151-1156.

Gryseels B, de Vlas SJ 1996. Worm burdens in schistosome infections. Parasitol Today 12: 115-119.

Grzych J-M, Pearce E, Cheever A, Caulada ZA, Caspar P, Heiny S, Lewis F, Sher A 1991. Egg deposition is the major stimulus for the production of Th2 cytokines in murine schistosomiasis mansoni. J Immunol 146: 1322-1327.

Haseeb MA, Craig JP 1997. Suppression of the immune-response to diphtheria toxoid in murine schistosomiasis. Vaccine 15: 45-50.

Hassanein H, Hanallah S, El-Ahwany E, Doughty B, El-Ghorab N, Badir B, Sharmy R, Zada S 2001. Immunolocalization of intercellular adhesion molecule-1 and leukocyte functional associated antigen-1 in schistosomal soluble egg antigeninduced granulomatous hyporesponsiveness. APMIS 109: 376-382.

Hayashi N, Matsui K, Hiroko H, Osada Y, Mohamed RT, Nakano H, Kashiwamura S, Hyodo Y, Takeda K, Akira S, Hada T, Higashino K, Kojima S, Nakanishi K 1999. Kupffer cells from Schistosoma mansoni-infected mice participate in the prompt type 2 differentiation of hepatic T cells in response to worm antigens. J Immunol 163: 6702-6711.

Henderson GS, Lu X, McCurley TL, Colley DG 1992. In vivo molecular analysis of lymphokines involved in the murine immune response during Schistosoma mansoni infection. II. Quantification of IL-4 mRNA, IFN- $\gamma$ mRNA and IL-2 mRNA levels in the granulomatous livers, mesenteric lymph nodes, and spleens during the course of modulation. $J$ Immunol 147: 2261-2269.

Henderson GS, Nix NA, Montesano MA, Gold D, Freeman GL, McCurley TL, Colley DG 1993. Two distinct pathologic syndromes in male CBA/J inbred mice with chronic Schistosoma mansoni infections. Am J Pathol 142: 703-714.

Hernandez HJ, Stadecker MJ 1999. Elucidation and role of critical residues of immunodominant peptide associated with T cell-mediated parasitic disease. J Immunol 163: 38773882. 
Hernandez HJ, Edson CM, Harn DA, Ianelli CJ, Stadecker MJ 1998. Schistosoma mansoni: genetic restriction and cytokine profile of the CD4+ T helper cell response to dominant epitope peptide of major egg antigen Sm-p40. Exp Parasitol 90: 122-130.

Hernandez HJ, Sharpe AH, Stadecker MJ 1999. Experimental murine schistosomiasis in the absence of B7 costimulatory molecules: reversal of elicited $\mathrm{T}$ cell cytokine profile and partial inhibition of egg granuloma formation. J Immunol 162: 2884-2889.

Hernandez HJ, Trzyna WC, Cordingley JS, Brodeur PH, Stadecker MJ 1997c. Differential antigen recognition by T cell populations from strains of mice developing polar forms of granulomatous inflammation in response to eggs of Schistosoma mansoni. Eur J Immunol 27: 666-670.

Hernandez HJ, Wang Y, Stadecker MJ 1997a. In infection with Schistosoma mansoni, B cells are required for T helper type 2 cells responses but not for granuloma formation. J Immunol 158: 4832-4837.

Hernandez HJ, Wang Y, Tzellas N, Stadecker MJ 1997b. Expression of class II, but not class I, major histocompatibility complex molecules is required for granuloma formation in infection with Schistosoma mansoni. Eur J Immunol 27: 1170-1176.

Hesse M, Cheever AW, Jankovic D, Wynn TA 2000. NOS-2 mediates the protective anti-inflammatory and anti-fibrotic effects of the Th1-inducing adjuvant, IL-12, in a Th2 model of granulomatous disease. Am J Pathol 157: 945-955.

Hesse M, Modolell M, LaFlamme AC, Schito M, Fuentes JM, Cheever AW, Pearce EJ, Wynn TA 2001. 1 Differential regulation of nitric oxide synthase-2 and arginase-1 by Type1/ type 2 cytokines in vivo: granulomatous pathology is shaped by the pattern of L-arginine metabolism. J Immunol 167: 6533-6544.

Hiatt RA, Ottesen EA, Sotomayor ZR, Lawly TJ 1980. Serial observations of circulating immune complexes in patients with acute schistosomiasis. J Inf Dis 142: 665-670.

Hoffman KF, Cheever AW, Wynn TA 2000. IL-10 and the dangers of immune polariaztion. Excessive type-1 and type- 2 cytokine responses induce distinct forms of lethal immunopathology in murine schistosomiasis. J Immunol 164: 64066416.

Hoffmann KF, McCarty TC, Segal DH, Chiaramonte M, Hesse M, Davis EM, Cheever AW, Meltzer PS, Morse HC III, Wynn TA 2001. Disease fingerprinting with cDNA microarrays reveals distinct gene expression profiles in lethal type- 1 and type- 2 cytokine-mediated inflammatory reactions. FASEB J 15: U233-U255.

Hogan LH, Weinstock JV, Sandor M 1999. TCR specificity in infection induced granulomas. Immunol Let 68: 115-120.

Houba V 1979. Experimental renal disease due to schistosomiasis. Kidney Int 16: 30-43.

Houba V, Sturrock RF, Butterworth AE 1977. Kidney lesions in baboons infected with Schistosoma mansoni. Clin Exp Immunol 30: 439-449.

Hsu SYL, Hsu HF, Lust GL, Davis JR, Eveland LK 1973. Comparative studies on the lesions caused by eggs of Schistosoma japonicum and Schistosoma mansoni in the liver of hamsters, guinea pigs, and albino rats. Ann Trop Med Parasitol 67: 349-356.

Hu JS, Frait KA, Reich F, Zhu Z, Elias JA, Chensue SW 2001. IL-13 transgene state impairs mycobacterial (Type-1) and schistosomal (Type 2) antigen-elicited responses. Cell Immunol 213: 114-121.

Jacobs W, Bogers J, Deelder A, Marck EV 1997b. Expression of intercellular adhesion molecule-1 and lymphocytefunction-associated antigen-1 in experimental Schisto- soma mansoni infection and in synchronous periparticular hepatic granulomas in mice: immunohistochemistry, confocal laser scanning microscopy, and immunoelectron microscopy. Parasitol Res 83: 405-412.

Jacobs W, Bogers J, Deelder A, Wéry M, Marck EV 1997a. Adult Schistosoma mansoni worms positively modulate soluble egg antigen-induced inflammatory hepatic granuloma formation in vivo. Am J Pathol 150: 2033-2045.

Jacobs W, Bogers JJ, Timmermans JP, Deelder AM, Van Marck EA 1998a. Adhesion molecules in intestinal Schistosoma mansoni infection. Parasitol Res 84: 276-280.

Jacobs W, Deelder A, Van Marck E 1999. Schistosomal granuloma modulation. II. Specific immunogenic carbohydrates can modulate schistosome-egg-antigen-induced hepatic granuloma formation. Parasitol Res 85: 14-18.

Jacobs W, van Dam G, Bogers J, Deelder A, Van Marck E 1998c. Schistosomal granuloma modulation. I. Schisosoma mansoni worm antigens CAA and CCA prime egg-antigen-induced hepatic granuloma formation. Parasitol Res 85: 7-13.

James SL 1995. Role of nitric oxide in parasitic infections. Microbiol Rev 59: 533-547.

Jankovic D, Sher A 1996. Initiation and regulation of CD4+ Tcell function in host-parasite models. Chem Immunol 63: 51-65.

Jankovic D, Cheever AW, Kullberg MC, Wynn TA, Yap G, Caspar P, Lewis FA, Clynes R, Ravetch JV, Sher A 1998. $\mathrm{CD}^{+}$cell-mediated granulomatous pathology in schistosomiasis is downregulated by a B cell-dependent mechanism requiring $\mathrm{Fc}$ receptor signaling. J Exp Med 187: 619629.

Jankovic D, Kullberg MC, Dobrowicz D, Barbieri S, Caspar P, Paul WE, Cheever AW, Kinet J-P, Sher A 1997. FceR1deficient mice infected with Schistosoma mansoni display defective IL-4 production from non-B, non-T cells as well as enhanced liver pathology. J Immunol 159: 1868-1875.

Jankovic D, Kullberg MC, Noben-Trauth N, Caspar P, Ward JM, Cheever AW, Paul WE, Sher A 1999. Schistosomeinfected IL-4 recepter knockout (KO) mice, in contrast to IL-4 KO mice, fail to develop granulomatous pathology while maintaining the same lymphokine expression profile. J Immunol 163: 337-342.

Jankovic D, Kullberg MC, Noben-Trauth N, Caspar P, Paul WE, Sher A 2000. Single cell analysis reveals that IL-4 receptor/Stat6 signaling is not required for the in vivo or in vitro development of CD4+ lymphocytes with a Th2 cytokine profile. J Immunol 164: 3047-3055.

Jesus, AR, Silva A, Santant LB, Magalhaes, A, Jesus AA, Almeida RP, Rego MA, Buratini MN, Pearce EJ, Carvalho EM 2002. Clinical and immunologic evaluation of 31 patients with acute schistosomiasis mansoni. J Inf Dis 185: 98-105.

Jones JT, Kusel JR 1985. The inheritance of responses to schistosomiasis mansoni in two pairs of inbred strains of mice. Parasitology 90: 289-300.

Jones JT, Breeze P, Kusel JR 1989. Schistosome fecundity: influence of host genotype and intensity of infection. Int $J$ Parasitol 19: 769-777.

Jones JT, McCaffery DM, Kusel JR 1983. The influence of the $\mathrm{H}-2$ complex on responses to infection by Schistosoma mansoni in mice. Parasitology 86: 19-30.

Joseph AL, Boros DL 1993. Tumor necrosis factor plays a role in Schistosoma mansoni egg-induced granulomatous inflammation. J Immunol 151: 5461-5471.

Junqueira LCU, Bignolas G, Brentani RR 1979. Picrosirius staining plus polarization microscopy, a specific method for collagen detection in tissue sections. Histochem $\mathrm{J}$ 11: 447-455. 
Kakizoe Y 1985. The influence of Schistosoma mansoni infection on carcinogenesis of mouse livers initiated by N-2flurenylacetamide. Kurume Med J 32: 169-178.

Kaplan MH, Whitfield JR, Boros DL, Grusby MJ 1998. Th2 cells are required for the Schistosoma mansoni egg-induced granulomatous response. J Immunol 160: 1850-1856.

Karanja DS, Colley DG, Nahlen BL, Ouma JH, Secor WE 1997. Evidence for immune-facilitated excretion of schistosome eggs from patients with Schistosoma mansoni and human immunodeficiency virus coinfection. Am J Trop Med Hyg 56: 515-521.

Kee CK, Taylor DW, Cordingley JS, Butterworth AE, Munro AJ 1986. Genetic influence on the antibody response to antigens of Schistosoma mansoni in chronically infected mice. Parasite Immunol 8: 565-574.

King CL, Xianli J, Malhotra I, Liu S, Mahmoud AAF, Oettgen HC 1997. Mice with a targeted deletion of the IgE gene have increased worm burdens and reduced granulomatous inflammation following primary infection with Schistosoma mansoni. J Immunol 158: 294-300.

Kloetzel K 1971. Tissue reactions to Schistosoma mansoni ova. III. Microcirculation in the intestine of infected mice, as studied by injection of contrast material. Rev Inst Med Trop São Paulo 13: 51-56.

Kloetzel K, Chieffi PP, Faleiros J, Merluzzi TJ Filho 1977. Mortality and other parameters of concomitant infections in albino mice: The Schistosoma-Toxoplasma model. Trop Geograph Med 29: 407-410.

Kloetzel K, Faleiros JJ, Mendes SR, Stanley CT, Arias HS 1973. Concomitant infection of albino mice by Trypanosoma cruzi and Schistosoma mansoni. Parasitological parameters. Trans $R$ Soc Trop Med Hyg 67: 652-658.

Knauft RF, Warren KS 1969. The effect of calorie and protein malnutrition on both the parasite and the host in acute murine schistosomiasis mansoni. J Inf Dis 120: 560-575.

Knight R, Warren, KS 1973. The interaction between Entamoeba Histolytica and Schistosoma mansoni infections in mice. Trans R Soc Trop Med Hyg 67: 644-651.

Kuntz RE, Malakatis GM 1955. Susceptibility studies in schistosomiasis. II. Susceptibility of wild mammals to infection by Schistosoma mansoni in Egypt, with emphasis on rodents. Am J Trop Med Hyg 4: 75-89.

La Flamme, AC, Patton EA, Pearce EJ 2001. Role of gamma interferon in the pathogenesis of severe schistosomiasis in Interleukin-4-deficient mice. Infect Immun 69: 7445-7452.

Langley JG, Boros DL 1995. T-lymphocyte responsiveness in murine schistosomiasis mansoni is dependent upon the adhesion molecules intercellular adhesion molecule-1, lymphocyte function-associated antigen-1 and very late antigen-4. Infect Immun 63: 3980-3986.

Lenzi HL, Kimmel E, Schechtman H, Pelajo-Machado M, Romanha WS, Pacheco RG, Mariano M, Lenzi JA 1998. Histoarchitecture of schistosomal granuloma development and involution: morphogenic and biomechanical approaches. Mem Inst Oswaldo Cruz 93 (Suppl. I): 141-151.

Lenzi HL, Kimmel E, Schechtman H, Pelajo-Machado M, Vale BS, Panasco MS, Lenzi JA 1999. Collagen arrangement in hepatic granuloma in mice infected with Schistosoma mansoni:dependence on fiber radiation centers. Braz J Med Biol Res 32: 639-643.

Lenzi HL, Lenzi JA, Rosman FC, Pelajo-Machado M, Mota EM, Panasco MS, Oliveira DN 1995. Extramedullary hematopoiesis in murine schistosomiasis mansoni. Mem Inst Oswaldo Cruz 90: 169-177.

Lenzi HL, Lenzi JA, Sobral ACL 1987. Eosinophils favor the passage of eggs to the intestinal lumen in schistosomiasis. Bras J Med Biol Res 20: 433-435.
Lenzi HL, Oliveira DN, Pelajo-Machado M, Borojevic R, Lenzi JA 1996. Coelom-associated lymphomyeloid tissue (milky spots): site of lymphoid and myelomonocytic cell generation. Braz J Med Biol Res 29: 19-24.

Lenzi JA, Mota EM, Pelajo-Machado M, Paiva RAN, Lenzi HL 1995. Calomys callosus: an alternative model to study fibrosis in schistosomiasis mansoni. The pathology of the acute phase. Mem Inst Oswaldo Cruz 90: 311-315.

Lenzi JA, Pelajo-Machado M, Mota EM, Oliveira DN, Panasco MS, Andrade ZA, Lenzi H 1998. Effects of Schistosoma mansoni infection on Calomys Callosus coelom-associated lymphomyeloid tissue (milky spots). Mem Inst Oswaldo Cruz 93 (Suppl. I): 13-23.

Lenzi JA, Mota EM, Pelajo-Machado M, Vale LS, Vela BS, Andrade ZA, Lenzi HL 2002. Intestinal fibrovascular nodules caused by Schistosoma mansoni infection in Calomys callosus Renger, 1830 (Rodentia: cricetidae): a model of concomitant fibrosis and angiogenesis. Mem Inst Oswaldo Cruz 97 (Suppl. I): 117-127.

Leptak CL, McKerrow JH 1997. Schistosome egg granulomas and hepatic expression of TNF- $\alpha$ are dependent on immune priming during parasite maturation. J Immunol 158: 301-307.

Lichtenberg F von, Sadun EH, Bruce JI 1962. Tissue responses and mechanisms of resistance in schistosomiasis mansoni in abnormal hosts. Am J Trop Med Hyg 11: 347-356.

Loos B 1964. Über die empfänglichkeit deutscher kleinsäugetiere (Rodentia und Insectivora) für experimentelle infektionen mit Schistosoma mansoni. Tropenmed Parasit 15: 55-94.

Lopes JD, Moreira AAB, Campos R, Kanamura HY, HoshinoShimzu S, Gayotto LCC, Silva, LCda 1981. Circulating antigens, antibodies and glomerular immune complexes in mice with unisexual Schistosoma mansoni infection. Rev Inst Med Trop São Paulo 23: 155-160.

LoVerde PT, Amento C, Higashi GI 1980. Parasite-parasite interaction of Salmonella typhimurium and Schistosoma mansoni. J Inf Dis 141: 177-185.

LoVerde PT, DeWald J, Minchella DJ, Bosshardt WC, Damian RT 1985. Evidence for host-induced selection in Schistosoma mansoni. J Parasitol 71: 297-301.

Lukacs NW, Boros DL 1991. Identification of larval cross-reactive and egg-specific antigens involved in granuloma formation in murine schistosomiasis mansoni. Infect Immunity 59: 3237-3242.

Lukacs NW, Boros DL 1993. Lymphokine regulation of granuloma formation in murine schistosomiasis mansoni. Clin Immunol Immunopathol 68: 57-63.

Lukacs NW, Chensue SW, Strieter RM, Warmington K, Kunkel SL 1994. Inflammatory granuloma formation is mediated by TNF- $\alpha$-inducible intercellular adhesion molecule-1. $J$ Immunol 152: 5883-5889.

Lukacs NW, Kunkel SL, Strieter RM, Warmington K, Chensue SW 1993. The role of macrophage inflammatory protein 1a in Schistosoma mansoni egg-induced granulomatous inflammation. J Exp Med 177: 1551-1559.

Lundy SK, Boros DL 2002. Fas ligand-expressing B-1a lymphocytes mediate CD4 ${ }^{+}$-T-cell apoptosis during schistosomal infection: induction by interleukin 4 (IL-4) and IL10. Infect Immun 70: 812-819.

Lundy SK, Lerman SP and Boros DL 2001. Soluble egg antigenstimulated $\mathrm{T}$ helper lymphocyte apoptosis and evidence for cell death mediated by FasL ${ }^{+} \mathrm{T}$ and $\mathrm{B}$ cells during murine Schistosoma mansoni infection. Infect Immun 69: 271 280.

Lwin M, Last C, Targett GAT, Doenhoff MJ 1982. Infection of mice concurrently with Schistosoma mansoni and rodent malarias: contrasting effects of patent $S$. mansoni infec- 
tions on Plasmodium chabaudi, $P$. yoelli and P. berghei. Ann Trop Med Parasitol 76: 265-273.

MacDonald AS, Patton EA, La Flamme AC, Araujo MI, Huxtable CR, Bauman B, Pearce EJ 2002. Impaired Th2 development and increased mortality during Schistosoma mansoni infection in the absence of CD40/CD154 interaction. J Immunol 168: 4643-4649.

Mansy SS, Yehia HA, Hassan MM, Hassan EA, Youssef MM, Hadi AAA, Mackenzie CD 1998. Effect of octreotide on the pathology of hepatic schistosomiasis. Drug Res 48: 855-861.

Maron R, Palanivel V, Weiner HL, Harn DA 1998. Oral administration of schistosome egg antigens and insulin $\beta$-chain generates and enhances Th2-type responses in NOD mice. Clin Immunol Immunopathol 87: 85-92.

Marshall AJ, Rosa Brunet L, van Gessel Y, Alcaraz A, Bliss SK, Pearce EJ, Denkers EY 1999. Toxoplasma gondii and Schistosoma mansoni synergize to promote hepatocyte dysfunction associated with high levels of plasma TNF- $\alpha$ and early death in C57BL/6 mice. J Immunol 163: 20892097.

Mathew RC, Boros DL 1986. Anti-L3T4 antibody treatment suppresses hepatic granuloma formation and abrogates antigen-induced interleukin-2 production in Schistosoma mansoni infection. Infect Immunity 54: 820-826.

Mathew RC, Ragheb S, Boros DL 1990. Recombinant IL-2 therapy reverses diminished granulomatous responsiveness in anti-L3T4-treated Schistosoma mansoni-infected mice. J Immunol 144: 4356-4361.

McClary H, Koch R, Chisari FV, Guidotti LG 2000. Inhibition of hepatitis B virus replication during Schistosoma mansoni infection in transgenic mice. J Exp Med 192: 289-294.

McKenzie GJ, Fallon PG, Emson CL, Grencis RK, McKenzie ANJ 1999. Simultaneous disruption of (IL)-4 and IL-13 defines individual roles in $\mathrm{T}$ helper cell Type 2-mediated responses. J Exp Med 189: 1565-1572.

Mendlovic F, Arnon R, Tarrab-Hazdai R, Puri J 1989b. Genetic control of immune response to a purified Schistosoma mansoni antigen. II. Establishment and characterization of specific I-A and I-E restricted T-cell clones. Parasite Immunol 11: 683-694.

Mendlovic F, Tarrab-Hazdai R, Puri DJ, Arnon R 1989a. Genetic control of immune response to a purified Schistosoma mansoni antigen. I. Effect of MHC class II antigens on the cellular, humoral and protective responses. Parasite Immunol 11: 667-682.

Metwali A, Elliott D, Blum AM, Jie L, Sabdor M, Liynch R, Noben-Trauth N, Weinstock JV 1996. The granulomatous response in murine schistosomiasis mansoni does not switch to Th1 in IL-4-deficient C57BL/6 mice. J Immunol 157: 4546-4533.

Metzger JM, Peterson LB 1988. Cyclosporin A enhances the pulmonary granuloma response induced by Schistosoma mansoni eggs. Immunopharmacol 15: 103-116.

Mola PW, Farah IO, Kariuki TM, Nyindo M, Blanton RE, King CL 1999. Cytokine control of the granulomatous response in Schistosoma mansoni-infected baboons: role of exposure and treatment. Infect Immunity 67: 6565-6571.

Montenegro SML, Miranda P, Mahanty S, Abath FGC, Teixeira KM, Coutinho EM, Brinkman J, Gonçalves I, Domingues LAW, Domingues ALC, Sher A, Wynn TA 1999. Cytokine production in acute versus chronic human schistosomiasis mansoni: the cross-regulatory role of interferon-gamma and interleukin-10 in the responses of peripheral blood mononuclear cells and splenocytes to parasite antigens. J Inf Dis 179: 1502-1514.

Montesano MA, Colley DG, Eloi-Santos S, Freeman GL, Secor
WE 1999a. Neonatal idiotypic exposure alters subsequent cytokine pathology, and survival patterns in experimental Schistosoma mansoni infections. J Exp Med 189: 637-645.

Montesano MA, Colley, DG, Freeman GL, Secor WE 1999b. Neonatal exposure to idiotype induces Schistosoma mansoni egg antigen-specific cellular and humoral immune responses. J Immunol 163: 898-905.

Montesano MA, Freeman GL, Gazzinelli G, Colley DG 1990a. Expression of cross-reactive, shared idiotypes of anti-SEA antibodies from humans and mice with schistosomiasis. $J$ Immunol 145: 1002-1008.

Montesano MA, Freeman GL, Gazzinelli G, Colley DG 1990b. Immune responses during human Schistosoma mansoni. XVII. Recognition by monoclonal anti-idiotypic antibodies of several idiotypes on a monoclonal anti-soluble schistosomal egg antigen antibody and anti-soluble schistosomal egg antigen antibodies from patients with different clinical forms of infection. J Immunol 145: 3095-3099.

Montesano MA, Freeman GL, Secor WE, Colley DG 1997. Immunoregulatory idiotypes stimulate $\mathrm{T}$ helper 1 cytokine responses in experimental Schistosoma mansoni infections. J Immunol 158: 3800-3804.

Morales-Montor J, Newhouse E, Mohamed F, Baghdadi A, Damian RT 2001. Altered levels of hypothalamic-pituitaryadrenocortical axis hormones in baboons and mice during the course of infection with Schistosoma mansoni. J Inf Dis 183: 313-20.

Morcos SH, Khayyal MT, Mansour MM, Saleh S, Ishak E, Girgis NI, Dunn MA 1983. Reversal of hepatic fibrosis after praziquantel therapy of murine schistosomiasis. Am J Trop Med Hyg 34: 314-321.

Moreels TG, de Man JG, Rogers JJ, de Winter, BY, Vrolix G, Herman AG, van Marck EA, Pelckmans PA 2001. Effect of Schistosoma mansoni-induced granulomatous inflammation on murine gastrointestinal motility. Am J Physiol Gastrointest Liver Physiol 280: G1030-G1042.

Mountford AP, Coulson PS, Cheever AW, Sher A, Wilson RA, Wynn TA 1999. Interleukin-12 can directly induce T-helper 1 responses in interferon-gamma (IFN-gamma) receptordeficient mice, but requires IFN-gamma signalling to downregulate T-helper 2 responses. Immunolology 97: 588594.

Nakazawa M, Fantappie MR, Freeman GL Jr, Eloi-Santos S, Olsen NJ, Kovacs WJ, Secor WE, Colley DJ 1997. Schistosoma mansoni: susceptibility differences between male and female mice can be mediated by testosterone during early infection. Exp Parasitol 815: 233-240.

Nassauw L van, Bogers J, Van Marck E, Timmermans JP 2001. Role of reactive nitrogen species in neuronal cell damage during intestinal schistosomiasis. Cell Tissue Res 303: 329336.

Natali PG, Cioli D 1976. Immune complex nephritis in Schistosoma mansoni-infected mice. Eur J Immunol 6: 359-364.

Njenga MN, Farah, IO, Muchemi GK, Nyindo M 1998. Periportal fibrosis of the liver due to natural or experimental infection with Schistosoma mansoni occurs in the Kenyan baboon. Ann Trop Med Parasit 92: 187-193.

Novato-Silva E, Gazzinelli G, Colley DG 1992. Immune responses during human schistosomiasis mansoni. XVIII. Immunologic status of pregnant women and their neonates. Scan J Immunol 35: 429-437.

Nyindo M, Farah IO 1999. The baboon as a non-human primate model of human schistosome infection. Parasitol Today 15: 478-482.

Olds GR, Meneza S el, Mahmoud AAF, Kresina TF 1989. Differential immunoregulation of granulomatous inflammation, portal hypertension, and hepatic fibrosis in murine 
schistosomiasis mansoni. J Immunol 142: 3605-3611.

Oliveira VR, El-Cheikh MC, Aguiar AM, Balduino A, Pinho MDB, Reis LFL, Borojevic R 2000. Schistosoma mansoni egg-induced hepatic granulomas in mice deficient for the interferon-gamma receptor have altered populations of macrophages, lymphocytes and connective tissue cells. $\mathrm{Mi}$ crobes \& Infect 2: 1817-1826.

O'Regan AW, Hayden JM, Body S, Liaw L, Mulligan N, Goetschkes M, Berman JS 2001. Abnormal pulmonary granuloma formation in osteopontin-deficient mice. Am J Respir Crit Care Med 164: 2243-2247.

Park MK, Hoffmann KF, Cheever AW, Amichay D, Wynn TA, Farber JM 2001. Patterns of chemokine expression in models of Schistosoma mansoni inflammmation and infection reveal relationships between type 1 and type 2 responses and chemokines in vivo. Infect Immun 69: 6755-6768.

Patton EA, La Flamme AC, Pedras-Vasconcelos JA, Pearce EJ 2002. Central role for Interleukin-4 in regulating nitric oxide-mediated inhibition of $\mathrm{t}$-cell proliferation and gamma interferon production in schistosomiasis. Infect Immun 70: 177-184.

Patton EA, Rosa Brunet L, La Flamme AC, Pedras-Vasconcelos J, Kopf M, Pearce EJ 2001. Severe schistosomiasis in the absence of Interleukin-4 (IL-4) is IL-12 independent. Infect Immun 69: 589-592.

Pearce EJ, McLaren D 1983. Reappraisal of the guinea-pig as an experimental host for studies of schistosomiasis mansoni. Parasitology 87: 455-464.

Pearce EJ, Cheever A, Leonard S, Covalesky M, FernandezBotran R, Kohler G, Kopf M 1996. Schistosomiasis in IL4 deficient mice. Internat Immunol 8: 435-444.

Pedras-Vasconcelos JA, Brunet LR, Pearce EJ 2001. Profound effect of the absence of IL-4 on T cell responses during infection with Schistosoma mansoni. J Leukoc Biol 70: 737-744.

Phillips SM, Ramadan MA, Zekavat AM, Hilliard B, Sugaya H el, Refaei M 1996. Regulation of the schistosome granuloma and fibrosis by TGF $\beta-1$ and antifibrotic chemotherapysafronil. Am J Trop Med Hyg 55: 191.

Phillips SM, Walker D, Abdel-Hafez SK, Linette GP, Doughty BL, Perrin PJ, Fathelbab N 1987. The immune response to Schistosoma mansoni infections in inbred rats. VI. Regulation by T cell subpopulations. J Immunol 139: 2781-2787.

Pinto PM, Brito CFA, Passos LKJ, Tendler M, Simpson AJG 1997. Contrasting genomic variability between clones from field isolates and laboratory populations of Schistosoma mansoni. Mem Inst Oswaldo Cruz 92: 409-414.

Portillo HA del, Damian RT 1986. Experimental Schistosoma mansoni infection in a small new world monkey, the saddleback tamarin (Saguinus fusicollis). Am J Trop Med Hyg 35: 515-522.

Powers KG, Cheever AW 1972. Comparison of geographical strains of Schistosoma mansoni in the rhesus monkey. Bull WHO 46: 295-300.

Prakash S, Robbins PW, Wyler DJ 1995. Cloning and analysis of murine cDNA that encodes a fibrogenic lymphokine, fibrosin. Proc Natl Acad Sci USA 92: 2154-2158.

Qiu B, Frait KAl, Reich F, Kornunlecki E, Chensue, SW 2001. Chemokine expression dynamics in mycobacterial (Type1) and schistosomal (Type-2) antigen-elicited pulmonary granuloma formation. Am J Pathol 155: 1503-1515.

Rakasz E, Blum AM, Metali A, Elliot DE, Li J, Ballas ZK, Qadir K, Lynch R, Weinstock JV 1998. Localization and regulation of IFN- $\gamma$ production within the granulomas of murine schistosomiasis in IL-4-deficient and control mice. J Immunol 160: 4994-4999.

Rathore Q, Sacristan C, Ricklan de, Flores Villanueva PO, Stadecker MJ 1996. In situ analysis of B7-2 costimulatory, major histocompatibility complex class II, and adhesion molecule expression in schistosomal egg granulomas. Am J Pathol 149: 187-194.

Remick DG, Chensue SW, Hiserodt JC, Higashi GI, Kunkel SL 1988. Flow-cytometric evaluation of lymphocyte subpopulations in synchronously developing Schistosoma mansoni egg and sephadex bead pulmonary granuolomas. Am J Pathol 131: 298-307.

Rezende SA, Lambertucci JR, Goes AM 1997c. Role of immune complexes from patients with different clinical forms of schistosomiasis in the modulation of in vitro granuloma reaction. Mem Inst Oswaldo Cruz, 92: 683-687.

Rezende SA, Oliveira VR, Silva AM, Alves JB, Goes AM, Reis LFL 1997a. Mice lacking the gamma interferon receptor have an impaired granulomatous reaction to Schistosoma mansoni infection. Infect Immunity 65: 3457-3461.

Rezende SA, Silva Teixeira DN, Drummond SC, Goes AM 1997b. IL-10 plays a role in the modulation of human granulomatous hypersensitivity against Schistosoma mansoni eggs induced by immune-complexes. Scand J Immunol 46: 96-102.

Richards CS, Shade PC 1987. The genetic variation of compatibility in Biomphalaria glabrata and Schistosoma mansoni. J Parasitol 73: 1146-1151.

Richter D, Harn DA, Matuschka F-R 1995. The irradiated cercariae vaccine model: looking on the bright side of radiation. Parasitol Today 11: 288-293.

Ritter DM, McKerrow JH 1996.Intercellular adhesion molecule 1 is the major adhesion molecule expressed during schistosome granuloma formation. Infect Immun 64: 4706-4713.

Rocha H, Oliveira VS, Oliveira MMG de 1980. The interaction of gram negative bacteria and $S$. mansoni in mice with experimental schistosomiasis. Mem Inst Oswaldo Cruz 75: 161-172.

Rosa Brunet L, Beall M, Dunne DW, Pearce EJ 1999b. Nitric oxide and the Th2 response combine to prevent severe hepatic damage during Schistosoma mansoni infection. $J$ Immunol 163: 4976-4984.

Rosa Brunet L, Finkelman FD, Cheever AW, Kopf MA, Pearce EJ 1997. IL-4 protects against TNF- $\alpha$ mediated cachexia and death during acute schistosomiasis. J Immunol 159: 777-785.

Rosa Brunet L, Sabin E, Cheever AW, Kopf MA, Pearce EJ 1999a. Interleukin 5 (IL-5) is not required for expression of a Th2 response or host resistance mechanisms during murine schistosomiasis mansoni but does play a role in development of IL-4-producing non-T, non-B cells. Infect Immunity 67: 3014-3018.

Roye O, Delacre M, William IR, Auriault C, Wolowczuk I 2001. Cutaneous interleukin-7 transgenic mice display a propitious environment to Schistosoma mansoni infection. Parasite Immunol 23: 133-140.

Rumbly CA, Sugaya H, Ali Zekavat S, Perrin PJ, Phillips SM 2001. Elimination of lymphocytes, but not eosinophils, by FAS-mediated apoptosis in murine schistosomiasis. Am J Trop Med Hyg 65: 442-449.

Rumbley CA, Sugaya H, Zekavat SA, Refaei ME, Perrin PJ, Phillips SM 1999. Activated eosinophils are the major source of Th2-associated cytokines in the schistosome granuloma. J Immunol 162: 1003-1009.

Rumbley CA, Zekavat AS, Sugaya H, Perrin PJ, Ramadan MA, Phillips SM 1998. The schistosome granuloma: charactrization of lymphocyte migration, activation, and cytokine production. J Immunol 161: 4129-4137.

Ruppel A, Rother U, Diesfeld HJ 1982. Schistosoma mansoni: development of primary infections in mice genetically deficient or intact in the fifth component of complement. Para- 
sitology 85: 315-323.

Ruth JR, Warmington KS, Shang XH, Lincoln P, Evanoff H, Kunkel SL, Chensue SW 2000. Interleukin 4 and 13 participation in mycobacterial (type-1) and schistosomal (type2) antigen-elicited pulmonary granuloma formation: multiparameter analysis of cellular recruitment, chemokine expression and cytokine networks. Cytokine 12: 432-444.

Rutitzky LI, Hernandez HJ, Stadecker MJ 2001. Th-1-polarizing immunization with egg antigens correlates with severe exacerbation of immunopathology and death in schistosome infection. PNAS 98: 13243-13248.

Sabin EA, Kopf MA, Pearce EJ 1996. Schistosoma mansoni egg-induced early IL-4 production is dependent upon IL-5 and eosinophils. J Exp Med 184: 1871-1878.

Sadek GA, Borges DR, Miszputen SJ 1986. Atividade dissacaridásica intestinal da esquistossomose mansônica. Estudo evolutivo em camundongos com diferentes cargas de infestação. Rev Inst Med Trop São Paulo. 28: 67-73.

Sadun EH, von Lichtenberg F, Bruce JI 1966. Susceptibility and comparative pathology of ten species of primates exposed to infection with Schistosoma mansoni. Am J Trop Med Hyg 15: 705-718.

Sadun EH, von Lichtenberg F, Cheever AW, Erickson DG 1970. Schistosoma mansoni in the chimpanzee: the natural history of chronic infections following single and multiple exposures. Am J Trop Med Hyg 19: 258-277.

Santos R de O, Barbosa Jr AA, Andrade ZA 1992. Dynamics of fibrosis production and resorption in intestinal schistosomiasis of mice. Mem Inst Oswaldo Cruz 87: 25-31.

Schiltz JR, Olds GR, Kresina TF, Mahmoud AAF 1988. Effect of chemotherapy on hepatic collagen and glycosaminoglycan metabolism in Schistosoma mansoni-infected mice. Trans $R$ Soc Trop Med Hyg 82: 868-873.

Schweitzer AN 1992. Alternative patterns of MHC-restricted antibody responsiveness following intraperitoneal immunization of inbred mice with different preparations of an 86 kilodalton antigen of Schistosoma mansoni. Parasite Immunol 14: 267-277

Schweitzer AN, Taylor DW 1991. MHC-restriction of antibody responses to an 86 kilodalton antigen of Schistosoma mansoni. Parasite Immunol 13: 261-266.

Secor WE, Powell MR, Morgan J, Wynn TA, Funk CD 1998. Mice deficient for 5-lipoxygenase, but not leukocyte type 12-lipoxygenase, display alter immune responses during infection with Schistosoma mansoni. Prostaglandins and Other Lipid Mediators 56: 291-304.

Segal BH, Doherty TM, Wynn TA, Cheever AW, Sher A, Holland SM 1999. The p47 phox-/- mouse model of chronic granulomatou disease has normal granuloma formation and cytokine responses to Mycobacterium avium and Schistosoma mansoni eggs. Infect Immun 67: 1659-1665.

Sher A, Coffman RL, Hieny S, Scott P, Cheever AW 1990. Interleukin 5 is required for the blood and tissue eosinophilia but not granuloma formation induced by infection with Schistosoma mansoni. Proc Nat Acad Sci USA 87: 6165.

Silva LM, Oliveira CN, Andrade ZA 2002. Neuroschistosomiasis. Inadequacy of the murine model. Mem Inst Oswaldo Cruz 97: 599-600.

Silva LCF, Borojovic R, Mourão PAS 1990. Identification of cells responsible for synthesis of sulphated glycosaminoglycans in schistosome-induced hepatic granulomas. Int J Exp Pathol 71: 845-856.

Smith JH, Doughty B, Kemp WM, Browder EJ, Mistry FD 1988. Experimental infection of the nine-banded armadillo (Dasypus novemcinctus) with Schistosoma mansoni (Kenyan strain). Am J Trop Med Hyg 38: 499-507.
Souza Vidal MRF, Barbosa AA, Andrade ZA 1993. Experimental pulmonary schistosomiasis: lack of morphological evidence of modulation in schistosomal pulmonary granulomas. Rev Inst Med Trop São Paulo 33: 423-429.

Stadecker MJ, Hernandez HJ 1998. The immune response and immunopathology in infection with Schistosoma mansoni: a key role of major egg antigen Sm-p40. Parasite Immunol 20: 217-221.

Stirewalt MA, Kuntz RE, Evans AS 1951. The relative susceptibilities of the commonly-used laboratory mammals to infection by Schistosoma mansoni. Am J Trop Med 31: 57-82.

Takahashi S, Kobayashi M 1982. Concanavalin A reduces liver collagen accumulation in murine schistosomiasis. Hepato$\log y 2: 249-254$.

Takahashi S, Simpser E 1981. Granuloma collagenase and EDTA-sensitive neutral protease production in hepatic murine schistosomiasis. Hepatology 1: 211-220.

Tawfik AF, Carter CE, Colley DG 1986. Effects of anti-schistosomal chemotherapy on immune responses, protection and immunity. I. Changes in cellular and humoral responses. Am J Trop Med Hyg 35: 100-109.

Thiongo FW, Madsen H, Ouma JH, Andreassen J, Christensen NO 1997. Host-parasite relationships in infections with two Kenyan isolates of Schistosoma mansoni in NMRI mice. J Parasitol 83: 330-332.

Todt JC, Whitfield JR, Ivard SR, Boros DL 2000. Down-regulation of interleukin-12, Interleukin-12R expression/activity mediates the sitch from Th1 to Th2 granuloma response during murine schistosomiasis mansoni. Scand J Immunol 52: 385-392.

Torrealba JF, Scorza JV, Dagert BC 1958. The experimental infection of some wild mammals from Venezuela with Schistosoma mansoni. Trans R Soc Trop Med Hyg 52: 565-569.

Trzyna WC, Cordingley JS 1993. Schistosoma mansoni: genetic non-response to $\mathrm{p} 40$, the major protein antigen of the egg, reveals a novel mechanism enhancing IgM production during infection. Parasite Immunol 15: 601-611.

Vaillant B, Chiramonte MG, Cheever AW, Soloway PD, Wynn TA 2001. Regulation of hepatic fibrosis and extracellular matrix genes by the Th response: new insight into the role of tissue inhibitors of matrix metalloproteinases. J Immunol 167: 7017-7026.

Valadares TE, Pereira LH 1983. Haematuria in experimental schistosomiasis mansoni. Trans R Soc Trop Med Hyg 77: 350-353.

Van Marck EAE, Deelder AM, Gigase PLJ 1977. Effect of partial portal vein ligation on immune glomerular deposits in Schistosoma mansoni-infected mice. Br J Exp Path 58: 412-417.

Varilek GW, Weinstock JV, Williams TH, Jew J 1991. Alteration of the intestinal innervation in mice infected with Schistosoma mansoni. J Parasitol 77: 472-478.

Vemgesa PB, Leese HJ 1979. Sugar absorption by the mouse small intestine following infection with Schistosoma mansoni. Trans $R$ Soc Trop Med Hyg 73: 55-60.

Verwaerde C, Thiam K, Delanoye A, Fernandez-Gomez R, D'Halluin J-C, Auriault C 1999. Systemic delivery of an adenovirus expressing EBV-derived vIL-10 in mice infected with Schistosoma mansoni or Leishmania amazonensis: controversial effects on the development of pathological parameters. Eur Cytokine Network 10: 161-170.

Viera LQ, Moraes-Santos T 1987. Schistosomiasis mansoni: evidence for a milder response in germ free mice. Rev Inst Med Trop São Paulo 29: 37-42.

Villanueva POF, Reiser H, Stadecker MJ 1994. Regulation to T helper cell responses in experimental murine schistosomiasis by IL-10. J Immunol 153: 5190-5199. 
Waine GJ, McManus DP 1997. Schistosomiasis vaccine development. The current picture. BioEssays 19: 435-443.

Wahl SM, Frazier-Jessen M, Jin WW, Kopp JB, Sher A, Cheever AW 1997. Cytokine regulation of schistosome-induced granuloma and fibrosis. Kidney Internat 51: 1370-1375.

Warmington KS, Boring L, Ruth JH, Sonstein J, Hogaboam CM, Curtis JL, Kunkel SL, Charo IR, Chensue SW 1999. Effect of C-C chemokine receptor 2 (CCR2) knockout on type-2 (schistosomal antigen-elicited) pulmonary granuloma formation - analysis of cellular recruitment and cytokine responses. Am J Pathol 154: 1407-1416.

Warren KS 1964. Experimental pulmonary schistosomiasis. Trans R Soc Trop Med Hyg 58: 228-233.

Warren KS 1966. The pathogenesis of "clay-pipe stem cirrhosis" in mice with chronic schistosomiasis mansoni, with a note on the longevity of the schistosomes. Am J Pathol 49: 477-489.

Warren KS, Domingo EO 1970. Schistosoma mansoni: stage specificity of granuloma formation around eggs after exposure to irradiated cercariae, unisexual infections, or dead worms. Exp Parasitol 27: 60-66.

Warren KS, Klein L 1969. Chronic murine hepatosplenic schistosomiasis mansoni: relative irreversibility after treatment. Trans $R$ Soc Trop Med Hyg 63: 333-337.

Warren KS, Peters PA 1967. Comparison of penetration and maturation of Schistosoma mansoni in the hamster, mouse, guinea pig, rabbit and rat. Am J Trop Med Hyg 16: 718-722.

Warren KS, Simões Jr J 1966. The marmoset: a primate resistant to Schistosoma mansoni infection. Am J Trop Med Hyg 15: 153-155.

Warren, KS, Rosenthal MS, Domingo EO 1969. Mouse hepatitis virus $\left(\mathrm{MHV}_{3}\right)$ infection in chronic murine schistosomiasis mansoni. Bull NY Acad Med 45: 211-224.

Water RDe, Van Marck EAE, Fransen JAM, Deelder AM 1988. Schistosoma mansoni: ultrastructural localization of the circulating anodic antigen and the circulating cathodic antigen in the mouse kidney glomerulus. Am J Trop Med Hyg 38: 87-124.

Weinstock JV 1992. Neuropeptides and the regulation of granulomatous inflammation. Clin Immunol Immunopathol 64: 17-22.

Weinstock JV, Boros DL 1981. Heterogeneity of the granulomatous response in the liver, colon, ileum, and ileal Peyer's patches to schistosome eggs in murine schistosomiasis mansoni. J Immunol 127: 1906-1909.

Weinstock JV, Boros DL 1983a. Organ-dependent differences in composition and function observed in hepatic and intestinal granulomas isolated from mice with schistosomiasis mansoni. J Immunol 130: 418-422.

Weinstock JV, Boros DL 1983b. Modulation of granulomatous hypersensitivity. VI. T lymphocyte subsets influence mast cell density in liver granulomas of Schistosoma mansoniinfected mice. J Immunol 131: 959-961.

Weinstock JV, Elliott D 1998. The substance P and somatostatin interferon-gamma immunoregulatory circuit. Neuroimmunobiology 840: 532-539.

Weinstock JV, Blum AM, Kassab JT 1985. Induction of granuloma modulation in murine schistosomiasis mansoni by enteric exposure to schistosome eggs. J Immunol 135: 560-
563.

Weinstock JV, Chensue SW, Boros DL 1983. Modulation of granulomatous hypersensitivity. V. Participation of histamine receptor positive and negative lymphocytes in the granulomatous response of Schistosoma mansoni-infected mice. J Immunol 130: 423-427.

Wolowczuk I, Delacre M, Roye O, Giannini SL, Auriault C 1997. Interleukin-7 in the skin of Schistosoma mansoniinfected mice is associated with a decrease in interferon- $\gamma$ production and leads to an aggravation of the disease. Immunology 91: 35-44.

Wolowczuk I, Nutten S, Roye O, Delacre M, Capron M, Murray RM, Trottein F, Auriault C 1999. Infection of mice lacking interleukin-7 (IL-7) reveals an unexpected role for IL-7 in the development of the parasite Schistosoma mansoni. Infect Immun 67: 4183-4190.

Wynn TA, Cheever AW 1995. Cytokine regulation of granuloma formation in schistosomiasis. Curr Opin Immunol 7: 505-511.

Wynn TA, Cheever AW, Jankovic D, Poindexter RW, Caspar P, Lewis FA, Sher A 1995a. An Il-12 based vaccination method for preventing fibrosis induced by schistosome infection. Nature 376: 594-596.

Wynn TA, Cheever AW, Williams ME, Hieny S, Caspar P, Kühn R, Müller W, Sher A 1998. interleukin-10 regulates liver pathology in acute murine schistosomiasis mansoni but is not required for immune down-modulation of chronic disease. J Immunol 160: 4473-4480.

Wynn TA, Eltoum I, Cheever AW, Lewis FA, Gause WC, Sher A 1993. Analysis of cytokine mRNA expression during primary granuloma formation induced by eggs of Schistosoma mansoni. J Immunol 151: 1430-1440.

Wynn TA, Eltoum I, Oswald IP, Cheever AW, Sher A 1994. Endogenous Interleukin 12 (IL-12) regulates granuloma formation induced by eggs of Schistosoma mansoni and exogenous IL-12 both inhibits and prophylactically immunizes against egg pathology. J Exp Med 179: 1551-1561.

Wynn TA, Jankovic D, Hieny S, Zioncheck K, Jardieu P, Cheever AW, Sher A 1995b. In the absence of endogenous IFN- $\gamma$, Interleukin-12 exacerbates rather than suppresses Th2-dependent pathology. J Immunol 154: 3999-4009.

Wynn TA, Morawetz R, Scharton-Kersten T, Hieny S, Morse HC III, Kuhn, R, Muller W, Cheever AW, Sher A 1997. Analysis of granuloma formation in double cytokine deficient mice reveals a central role for IL-10 in polarizing both th1 and th2-type cytokine responses in vivo. J Immunol 159: 5014-5023.

Yamashita T, Boros DL 1992. IL-4 influences IL-2 production and granulomatous inflammation in murine schistosomiasis mansoni. J Immunol 149: 3659-3664.

Yap G, Cheever A, Caspar P, Jankovic D, Sher A 1997. Unimpaired down-modulation of the hepatic granulomatous response in CD8T cell and IFN-g deficient mice chronically infected with Schistosoma mansoni. Infect Immun 65: 25832586.

Zhu Y, Lukacs NW, Boros DL 1994. Cloning of Th0 and Th2type helper lymphocytes from liver granulomas of Schistosoma mansoni-infected mice. Infect Immun 62: 994-999. 